\title{
Seasonal, interannual and decal variability of Tropospheric Ozone in the North Atlantic: Comparison of UM-UKCA and remote sensing observations for 2005-2018
}

Maria R. Russo ${ }^{1,2}$, Brian J. Kerridge ${ }^{3,4}$, Nathan Luke Abraham ${ }^{1,2}$, James Keeble ${ }^{1,2}$, Barry G. Latter ${ }^{3,4}$, 5 Richard Siddans $^{3,4}$, James Weber ${ }^{5}$, Paul T. Griffiths ${ }^{1,2}$, John A. Pyle ${ }^{1,2}$ and Alexander T. Archibald ${ }^{1,2}$

${ }^{1}$ NCAS National Centre for Atmospheric Science, Cambridge, UK

${ }^{2}$ University of Cambridge, Cambridge, UK

$10 \quad{ }^{3}$ Remote Sensing Group, STFC Rutherford Appleton Laboratory, Didcot, UK

${ }^{4}$ NERC National Centre for Earth Observation, Rutherford Appleton Laboratory, Didcot, UK

${ }^{5}$ University of Sheffield, Department of Biosciences, Sheffield, UK; previously at University of Cambridge, UK

Correspondence to: Maria R. Russo (mrr32@cam.ac.uk)

15 Abstract

Tropospheric ozone is an important component of the Earth System as it can affect both climate and air quality. In this work we use observed tropospheric column ozone derived from the Ozone Monitoring Instrument (OMI) and Microwave Limb Sounder (MLS) OMI-MLS, in addition to OMI ozone retrieved in discrete vertical layers, and compare it to tropospheric ozone from UM-UKCA simulations (which utilise the Unified Model, UM, coupled to UK Chemistry and Aerosol, UKCA).

20 Our aim is to investigate recent changes (2005-2018) in tropospheric ozone in the North Atlantic region, and specifically its seasonal, interannual and decadal variability and to understand what factors are driving such changes. Through sensitivity experiments, timeseries correlation and comparison with the LIS-OTD lightning flash dataset, the model positive bias in the Tropics is attributed to shortcomings in the convection and lightning parameterisations. Use of OMI data, for which vertical averaging kernels and a priori information are available, suggests that the model negative bias at mid latitudes relative to

25 OMI-MLS tropospheric column could be the result of vertical sampling. Ozone in the North Atlantic peaks in spring and early summer, with generally good agreement between the modelled and observed seasonal cycle. Recent trends in tropospheric ozone were investigated and the discrepancy between model and observations was linked to possible differences in lower stratospheric ozone trends and associated stratosphere to troposphere transport. Modelled tropospheric ozone interannual variability (IAV) is driven by IAV of tropical emissions of NOx from lightning and IAV of ozone

30 transport from the stratosphere; however, the modelled and observed IAV differ. To understand the IAV discrepancy we investigated how modelled ozone and its drivers respond to large scale modes of variability. Using OMI height-resolved data and model idealised tracers, we were able to identify stratospheric transport of ozone into the troposphere as the main driver of the dynamical response of North Atlantic ozone to the Arctic Oscillation (AO) and the North Atlantic Oscillation (NAO). 
Finally, the ozone response to El Nino Southern Oscillation (ENSO) and its impact on observed and modelled north Atlantic ozone variability was analysed.

\section{Introduction}

Ozone $\left(\mathrm{O}_{3}\right)$ is an important reactive gas present in both the troposphere and the stratosphere. In the stratosphere, ozone is mainly produced following the photolysis of oxygen molecules $\left(\mathrm{O}_{2}\right)$ by solar ultraviolet radiation. Tropospheric ozone is a greenhouse gas and an oxidant; it can therefore affect climate directly, through its radiative impact, and indirectly, through the oxidation of aerosol precursors and changes to the aerosols' radiative impact (Karset et al., 2018). Tropospheric ozone is formed by photochemical oxidation of volatile organic compounds (VOCs) in the presence of nitrogen oxides $\left(\mathrm{NOx}=\mathrm{NO}+\mathrm{NO}_{2}\right)$ and sunlight; VOCs and NOx are known as 'ozone precursors' (Archibald et al., 2020a; Monks et al., 2015). The increase in anthropogenic emissions of ozone precursors over the last 150 years has led to an estimated $40 \%$ increase in the burden of tropospheric ozone (Archibald et al., 2020a; Griffiths et al., 2021; Young et al., 2013) as simulated

45 by chemistry-climate models (CCMs). As well as being chemically produced in the troposphere, a large fraction of tropospheric ozone comes from downward transport of ozone-rich stratospheric air-masses into the troposphere (Skerlak et al., 2014; Young et al., 2018; Archibald et al., 2020a). Stratosphere to Troposphere Transport (STT) is particularly important at mid-latitudes, around $30^{\circ} \mathrm{N}$ and $30^{\circ} \mathrm{S}$, where the descending branches of the Hadley and Ferrel cells cause a general downward motion of lower stratospheric air into the troposphere; this results in local stratospheric ozone transport that peaks

50 in late spring and early summer (Skerlak et al., 2014; Yang et al., 2016; Williams et al., 2019). The extent of the stratospheric contribution to tropospheric ozone has been extensively investigated in recent decades (e.g., Lamarque et al., 1999; Neu et al., 2014; Skerlak et al., 2014; Williams et al., 2019; Abalos et al., 2020), however, recent improvements in diagnostic and modelling tools provide evidence that stratospheric ozone has a significant influence on tropospheric ozone trends (e.g., Griffiths et al., 2020) and interannual variability (Terao et al., 2008; Neu et al., 2014; Liu et al., 2020), with STT estimated to contribute up to $\sim 50 \%$ of tropospheric ozone in the wintertime extratropics (Williams et al., 2019; Abalos et al., 2020) and projected to play an increasingly important role due to the predicted strengthening of the Brewer Dobson circulation (Butchart, 2014) and possible future reduction in anthropogenic ozone precursor emissions (Archibald et al., 2020a).

$60 \mathrm{CCM}$ simulations show that the greatest increases in tropospheric ozone since the pre-industrial period occur in the Northern Hemisphere and can be attributed to the dramatic increase in precursor emissions in this region (Young et al., 2013; Griffiths et al., 2021). Observational records are limited and do not allow a complete assessment of the pre-industrial to present day trends in tropospheric ozone (Tarrasick et al., 2019) but isotopic evidence supports the general conclusions from CCM simulations of a significant increase in the tropospheric burden since the pre-industrial period (Yeung et al., 2019). The 
and interannual variations of tropospheric ozone. Ozone sondes and aircraft measurements give insight into the vertical structure of ozone, whilst measurements from surface stations provide accurate data on the local scale and have been used to estimate ozone trends (e.g., Cooper et al., 2020). However, in situ measurements are geographically sparse and often sample small scale, local features that can be hard for global climate models to reproduce and attribute. As observational records of ozone from satellite platforms increase in length, spanning decades now, they have become an invaluable tool in trying to understand the global tropospheric ozone budget and trends (Archibald et al., 2020b; Heue et al., 2016; Gaudel et al., 2018; Ziemke et al., 2019). In order to investigate recent tropospheric ozone variability this work uses a combination of different satellite ozone measurements and modelled ozone fields.

75 OMI-MLS Tropospheric Column Ozone (TCO) is a well documented (Ziemke et al., 2006) and well established TCO dataset. The ozone column between the surface and the tropopause is derived by subtraction of the Microwave Limb Sounder (MLS) stratospheric column from the Ozone Monitoring Instrument (OMI) total column. This dataset has been extensively used in recent studies as a standard for model ozone evaluation (Martin et al., 2007; Young et al., 2013; Gaudel et al., 2018; Archibald et al., 2020b; Griffiths et al., 2021). One problem with using TCO for model evaluation is that ozone

80 has a large gradient around the tropopause, with very high concentrations in the lower stratosphere. Because of this, small differences between the model and OMI-MLS definitions of the tropopause can lead to significant differences between modelled and observed TCO (Griffiths et al., 2021). Furthermore, because of the way OMI-MLS TCO is derived, it is not possible to correct for its vertical sensitivity through application of averaging kernels (AK) to the model data. Although neglect of vertical sensitivity makes model comparison with this dataset quicker and less data intensive (and therefore favoured by modellers in the literature), it could influence the comparison of models and observations.

To address the problems described above, OMI-MLS TCO measurements were complemented with ozone data retrieved from the OMI instrument on discrete vertical layers by the Rutherford Appleton Laboratory (RAL) scheme (based on Miles et al., 2015). Because OMI subcolumns are defined independently of the tropopause, they are not subject to the uncertainty 90 associated with tropopause definition and the lower troposphere is well-resolved. Furthermore, differences in vertical sampling between model and OMI subcolumns can be reduced through a fairly simple approach whereby OMI monthly mean, gridded AKs and a priori information are applied to the monthly mean modelled ozone data, similar to Williams et al. (2019). The errors arising from using monthly mean satellite operators on monthly mean modelled data has been investigated by Aghedo et al. (2011) who compared model data to Tropospheric Emissions Spectrometer, TES, data; they found only a 95 small difference $(\sim 1-2 \%)$ in zonal mean ozone concentrations using monthly mean data compared to a more complex approach where satellite operators are applied to modelled ozone using 3-hourly data. The OMI Lower Tropospheric Column Ozone (LTCO), defined between the surface and $450 \mathrm{hPa}$ (or $\sim 0-6 \mathrm{~km}$ ), provides a measure of ozone in the lower free troposphere. We also use OMI data retrieved in the following two layers: 450-170 hPa ( 6-13 km) and 170-50 hPa ( 13-20 km); these span the upper troposphere and lower stratosphere and can help to evaluate ozone in the North Atlantic 
region. Since ozone is not vertically homogeneous in the troposphere, insight can be gained by differentiating between the lower and upper troposphere, where ozone has different sources, sinks and lifetimes, (Lelieveld and Dentner, 2000).

The North Atlantic region is a key region of change in tropospheric ozone (Robson et al., 2018). Understanding decadal changes in ozone and its drivers can help us predict future changes in North Atlantic ozone and how to mitigate its impact on, for example, exacerbating air quality problems. The link between the Arctic Oscillation (AO) or North Atlantic Oscillation (NAO) and ozone in the North Atlantic has long been investigated (Creilson et al., 2003; Lamarque and Hess, 2004; Creilson et al., 2005; Hess and Lamarque, 2007; Pausata et al., 2012; Pope et al., 2018). Surface ozone anomalies over Northern Europe were shown to correlate strongly to the NAO (Pausata et al., 2012) and this was attributed to increased westerly flow across the North Atlantic leading to increased transport of pollutants from the US to Europe during a positive

110 NAO phase. However, the response of North Atlantic ozone to the AO/NAO has been shown to vary with height and location. Lamarque and Hess (2004) found a strong correlation across the vertical column between the Spring AO and ozonesonde data for the US, while data for Europe showed the strongest correlation with the AO at higher altitudes (with maximum at $\sim 200 \mathrm{hPa}$ ). Similarly, Pope et al. (2018) showed the difference in observed ozone between positive and negative Winter NAO phases varies with height and location across the North Atlantic. Pausata et al. (2012) analysed modelled ozone

115 anomalies in the North Atlantic and suggested that whilst surface ozone correlation to the NAO can be explained by long range transport of ozone and ozone precursors, the downward transport of stratospheric air might play a larger role in the tropospheric column, particularly in Winter and Spring.

This work is part of a coordinated effort to characterise the climate and composition of the North Atlantic region (Sutton et al., 2018, BAMS). Recent changes in the North Atlantic climate system have occurred for a number of physical and chemical variables and have been highlighted in Robson et al. (2018). Significant decadal variability has been observed for the North Atlantic Oscillation and the jet speed (Hurrell, 1995; Woollings et al., 2015), ocean heat and salinity content (Robson et al., 2016; Reverdin, 2010), sea ice extent (Swart et al., 2015), and ocean transports (Smeed et al., 2018). Ozone trends in the North Atlantic can be influenced by a variety of factors. Anthropogenic emissions of ozone precursors have been decreasing in the US and Europe in the last few decades as a result of air quality policies, therefore potentially contributing to a decrease in tropospheric ozone over this period (Archibald et al., 2020a). However, because of the relatively long lifetime of free-tropospheric ozone, 20-30 days (Young et al., 2013; Monks et al., 2015), North Atlantic ozone concentrations can also be affected by hemispheric transport of ozone generated by emissions outside of the local region (e.g., Butler et al., 2018). Other potential factors contributing to North Atlantic ozone trends include changes in 130 tropical biogenic and biomass burning emissions, tropical NOx emissions from lightning and transport of ozone rich air from the stratosphere. Several studies have tried to characterise ozone trends in the North Atlantic region using surface and satellite observations (Cooper et al., 2014; Parrish et al., 2014; Ebojie et al., 2016; Oetjen et al., 2016; Heue et al., 2016; Gaudel et al., 2018; Cooper et al., 2020); however, these studies do not provide a consistent picture regarding the sign and 
magnitude of recent ozone trends. Such inconsistencies can arise from the high spatial, vertical and temporal variability of ozone which can result in different trends being calculated when different periods or different locations are analysed.

Our focus in this study is to investigate recent changes (2005-2018) in tropospheric ozone in the North Atlantic using satellite observations and a state-of-the-art chemistry climate model, the UK Chemistry and Aerosol (UKCA); UKCA (Archibald et al., 2020b) is the chemistry and aerosol component of the UK Earth System Model, UKESM1 (Sellar et al.,

140 2019). Our aim is to investigate tropospheric ozone seasonal, interannual and decadal variability and to understand what factors are driving such changes. We also aim to investigate the role of large scale modes of variability, such as the Arctic Oscillation (AO), North Atlantic Oscillation (NAO) and El Nino Southern Oscillation (ENSO), on North Atlantic ozone inter annual variability (IAV). Satellite observations on discrete atmospheric layers are used as an additional benchmark for model evaluation and to improve our understanding of the chemical and dynamical processes affecting tropospheric ozone.

Model configuration, observational datasets and numerical methods used in this paper are described in section 2; in section 3 we analyse observed and modelled tropospheric ozone climatology in the North Atlantic, including seasonal variations, and address possible reasons for the discrepancy between model and observations; in section 4 we discuss tropospheric ozone interannual and decadal variability in the North Atlantic and what drives ozone variability and trends; conclusion of this work are presented in section 5 .

\section{Technical details}

\subsection{Model Description}

Model simulations of the UKCA chemistry climate model were performed with a horizontal grid of $1.875^{\circ} \times 1.25^{\circ}$ and 85 vertical levels with a model top at $80 \mathrm{~km}$. The specific configuration is a combination of the StratTrop chemistry scheme coupled to Global Atmosphere 7.1 (Walters et al., 2019), and has been described in Archibald et al. (2020b). The UKCA StratTrop scheme merges the stratospheric scheme described in Morgenstern et al. (2009) with the tropospheric "TropIsop" scheme described in O'Connor et al. (2014). UKCA-StratTrop describes the chemical processing of the organic compounds - methane, ethane, propane and isoprene and their oxidation products - coupled to the inorganic chemistry of Ox, NOx, $\mathrm{HOx}, \mathrm{ClOx}$ and $\mathrm{BrOx}$, including heterogeneous processes on polar stratospheric clouds and liquid sulphate aerosols. For more details on this model and a general model evaluation, the reader is referred to Archibald et al. (2020b) and references therein.

In this work we use nudged model integrations wherein the model meteorology is relaxed toward the ECMWF's ERAInterim reanalysis (Dee et al., 2011) using the nudging functionality in the MetUM (Telford et al., 2008). Nudging is applied to model temperature and winds from about $1.2 \mathrm{~km}$ to $65 \mathrm{~km}$ (maximum height of ERA data) using an e-folding relaxation 
timescale of $6 \mathrm{~h}$. CMIP6 emissions (Feng et al., 2020) are used to drive the modelled chemistry; historical emissions are used up to 2014 and SSP3-7.0 from 2015-2018.

In order to identify the impact of transport on modelled tropospheric ozone in the North Atlantic, we used two idealised tracers, $\mathrm{O} 3 \mathrm{~S}$ and $\mathrm{O} 3 \mathrm{~S}-\mathrm{C}$, which represent ozone transported from the stratosphere and stratosphere to troposphere transport, respectively. The O3S tracer is set to the same values as stratospheric ozone in the stratosphere and decays following ozone chemical loss reactions in the troposphere and has been used in previous studies (e.g., CCMI simulations). The O3S-C is defined similarly to $\mathrm{O} 3 \mathrm{~S}$ in the troposphere (i.e. decays with the same chemical loss reactions), but its stratospheric concentration is homogeneous in space and constant in time. O3S-C therefore gives a complementary measure of downward transport from the stratosphere which is not affected by stratospheric ozone geographical distribution or trends. The pair of O3S and O3S-C tracers therefore allow us to quantify the effects of STT on tropospheric ozone and isolate the effects of stratospheric circulation and dynamical trends on STT vs those from changes in the burden and distribution of lower stratospheric ozone.

\subsection{Observations}

This study uses observations by the Ozone Monitoring Instrument (OMI) and Microwave Limb Sounder (MLS) on NASA's Aura satellite. OMI is a nadir-viewing UV/VIS solar backscatter spectrometer with 13 x 24km horizonal sampling. Spectra

180 in the Huggins bands are used to retrieve total column ozone. The OMI-MLS tropospheric column ozone (TCO) is determined by subtracting the MLS stratospheric column ozone (Waters et al., 2006) from the OMI (Levelt et al., 2006) total column ozone. The algorithm used to produce the tropospheric ozone column is described in Ziemke et al. (2006, 2019), and the monthly, gridded data product is available between $60^{\circ} \mathrm{S}: 60^{\circ} \mathrm{N}$ with a horizontal resolution of $1^{\circ} \times 1.25^{\circ}$. The data was downloaded from https://acd-ext.gsfc.nasa.gov/Data_services/cloud_slice/new_data.html in July 2020.

OMI measurements of Hartley and Huggins bands spectra are used to retrieve ozone profiles spanning the stratosphere and troposphere. The height-resolved ozone dataset used in this study was produced by the Remote-Sensing Group at Rutherford Appleton Laboratory (RAL) using a profile retrieval scheme based on a method first developed for the GOME series of instruments (Miles et al., 2015) and applied to produce multi-year data sets from a series of UV/VIS sounders for ESA's

190 Climate Change Initiative and EU's Copernicus Climate Change Service. Surface-450hPa, 450-170hPa and 170-50hPa layer amounts from individual soundings were gridded to monthly data with a horizontal resolution of $1.5^{\circ} \times 1.5^{\circ}$.

A bias correction, derived with respect to a multi-year ensemble of ozonesondes as a function of latitude and month of year, has been applied to each OMI subcolumn (for more details on the bias correction see supplementary Figure 0).

OMI is the first of a new class of uv/vis sounder which uses 2-D detector arrays rather than scanning 1-D arrays to scan

195 across-track. However, across-track sampling is limited by an obstruction to its field-of-view (the so-called row anomaly) which changes over the course of the mission and particularly limits sampling in the northern hemisphere. The reduction in across-track sampling over time has the largest impact in the Northern mid-latitudes and, although it does not seriously affect 
the multi-year mean ozone distribution, it results in larger uncertainties in the trend estimates for the lower troposphere subcolumn. A measure of this uncertainty is provided in Figure 6. Other OMI subcolumns are less sensitive to these issues and show much smaller uncertainties in both climatological ozone distribution and trends.

The BSVertOzone (Bodeker Scientific Vertical Ozone) is a global, vertically resolved, monthly mean, zonal mean ozone dataset; this dataset includes data from satellites and ozone sondes and covers the period from 1979 to 2016. For more details the reader is directed to Hassler et al. (2018). The data was downloaded from https://zenodo.org/record/1217184\#.YbchxS$\underline{12 X 1}$ in March 2020.

The LIS-OTD dataset combines data from the Optical Transient Detector (OTD) and the Lightning Imaging Sensor (LIS) to measure lightning flash rates on the global scale (Cecil, 2006; Cecil et al., 2014) and is provided by the NASA Global Hydrology Resource Center (GHRC). In this study we use version 2.3 of the low resolution monthly timeseries (LRMTS, downloaded from https://ghrc.nsstc.nasa.gov/hydro/details/lolrmts in Sep 2019) which provides monthly gridded data at a resolution of $2.5^{\circ} \times 2.5^{\circ}$. OTD flew from 1995 to 2000 on the MicroLab-1 satellite (Christian et al., 2003). LIS has been deployed on the Tropical Rainfall Measuring Mission (TRMM) satellite from 1997 to 2015 (Bocippio et al., 2003). These space-based optical lightning sensors detect both Cloud-to-ground (CG) and cloud to cloud (CC) discharges and are well suited for determining how lightning is distributed across the Earth's surface.

\section{2.3 Data Processing}

For comparison with OMI-MLS data, the modelled ozone tropospheric column is calculated by vertically integrating the model ozone between the surface and the tropopause (defined as $380 \mathrm{~K}+2 \mathrm{PV}$ ). Alternative definitions of tropopause have also been used to address the sensitivity of our results to the choice of tropopause: these include the World Meteorological Organization (WMO) $2 \mathrm{~K} \mathrm{~km}^{-1}$ thermal vertical gradient and 125 ppbv ozonopause.

To ensure consistent comparison between OMI and UKCA ozone we used monthly, gridded averaging kernels and a priori information to minimise vertical sampling differences between model and observations (similar to Williams et al., 2019). Modelled ozone data was first regridded on the OMI horizontal grid; model gridpoints for which observational data are not available (due to cloud screening, solar zenith angle and other sampling limitations at high latitudes) were removed; the remaining co-located spatial and temporal gridpoints (function of latitude, longitude and time) were interpolated vertically to match the pressure levels of the observations, then sampled using the OMI a priori and averaging kernel information (as described in equation 1 ):

$$
x^{s}=x^{a}+\mathbf{A}\left(x^{m}-x^{a}\right)
$$


where $\boldsymbol{x}^{s}$ is the model gridded ozone profile sampled as OMI, $\boldsymbol{x}^{\boldsymbol{a}}$ is the OMI a priori gridded profile, $\boldsymbol{x}^{\boldsymbol{m}}$ is the model gridded ozone profile (interpolated on OMI pressure levels) and $\mathbf{A}$ is the gridded OMI averaging kernel matrix. Finally, the model data was integrated vertically to produce ozone subcolumns consistent with the OMI subcolumns.

Although potential issues with using monthly mean, rather than averaging kernels for individual profiles, can arise for certain species and instruments (von Clarmann and Glatthor, 2019), agreement between model and observations was found to be improved substantially through application of monthly mean averaging kernels in this analysis, in agreement with 235 previous work (Aghedo et al., 2011; Williams et al., 2019).

Trends were calculated using a least square linear regression method on monthly, deseasonalised timeseries. The standard error of the trend estimate has been calculated from the standard deviation of the residuals (Wigley 2006). The effect of autocorrelation has been included by using the lag-one autocorrelation coefficient to determine an effective sample size in the calculation of the standard error of the trend estimate (Wigley 2006; Santer et al., 2000).

\section{Tropospheric ozone climatology: geographical distribution and seasonality}

Unless stated otherwise, all plots in this section use data from Jan 2005 to Dec 2018. Analysis of TCO from OMI-MLS is supplemented by analysis of LTCO from the lowest OMI subcolumn (surf-450 hPa) and upper tropospheric column ozone (UTCO) from OMI subcolumn 450-170 $\mathrm{hPa}$. Where quantities are presented as a regional average for the North Atlantic, the

245 latitude-longitude coordinates are defined as $0^{\circ}: 60^{\circ} \mathrm{N}$ and $100^{\circ} \mathrm{W}: 30^{\circ} \mathrm{E}$; for consistency, these are the same coordinates used to plot the regional maps. For line plots showing domain averages we chose to analyse mid latitude north Atlantic (MNA) between $30^{\circ} \mathrm{N}: 60^{\circ} \mathrm{N}$ and tropical north Atlantic (TNA) between $0^{\circ}: 30^{\circ} \mathrm{N}$, as well as the North Atlantic domain as a whole; this is because chemical and dynamical drivers of tropospheric ozone in the Tropics can be different from those at mid latitudes.

\section{3.1 Observed vs Modelled tropospheric ozone Climatology in the North Atlantic}

We start our analysis by investigating the geographical distribution of tropospheric ozone in the North Atlantic using multiannual mean maps. 

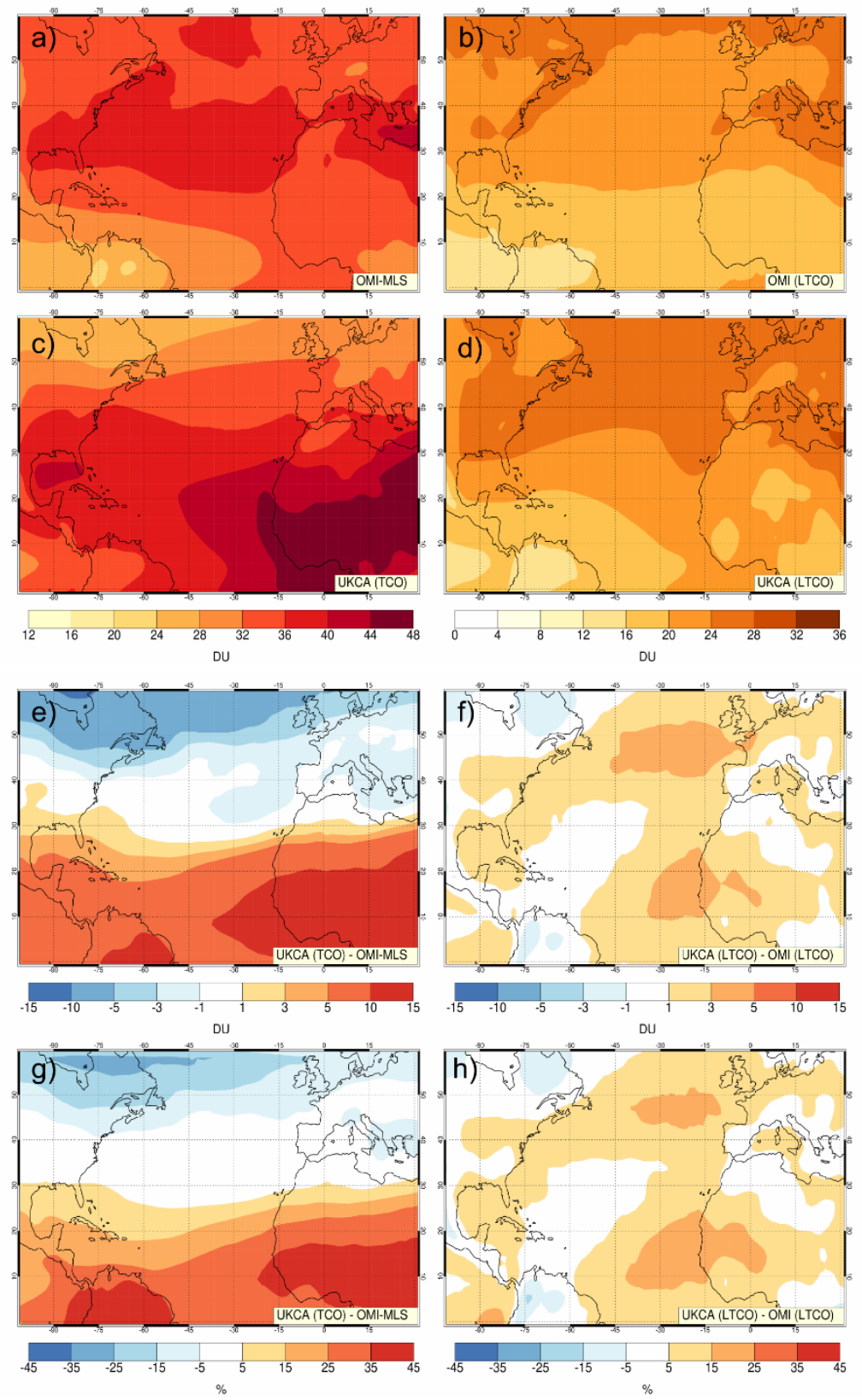

Figure 1: Tropospheric ozone multiannual means for the period 2005-2018. a) OMI-MLS TCO; b) OMI LTCO; c) UKCA TCO; d) UKCA LTCO. Difference between modelled and observed: e) UKCA TCO - OMI-MLS; f) UKCA LTCO - OMI LTCO; g and $h$ are the same as e and $f$ but expressed as a percentage difference.

Figure 1 shows observed and modelled ozone columns and their absolute and percentage difference for both TCO (left column) and LTCO (right column). Observed TCO (Fig 1a) shows a local maximum around $30^{\circ} \mathrm{N}: 40^{\circ} \mathrm{N}$ with generally lower ozone values over the tropical part of the domain; in contrast, UKCA TCO (Fig 1c) has larger values in the tropical 
part of the domain, with a pronounced local maximum over Northern Africa, resulting in an overestimate of observed TCO for large parts of the Tropical North Atlantic. Difference maps (Fig 1e and 1g) show a significant discrepancy between modelled and observed TCO in the southern North Atlantic, with biases greater than 10 DU or $\sim 40 \%$ for a large area in the tropics; at mid latitudes the model underestimates TCO by $\sim 6-10$ DU or $\sim 20 \%$. Comparison of observed and modelled LTCO is shown in Figure $1 \mathrm{~b}$ and 1d: the model exhibits a relatively small positive bias of $\sim 2-4$ DU or $\sim 10-20 \%$ (Fig $1 \mathrm{f}$ and 1h) over a large part of the North Atlantic. This bias is considerably smaller than the model bias in TCO. Williams et al. 2019 compared OMI ozone column in the lower troposphere with EMAC and CMAM models and found a widespread (global) positive bias between EMAC and OMI LTCO.

To understand the seasonality of North Atlantic ozone we analyse multiannual mean seasonal cycles (Fig 2) averaged over the following domains: North Atlantic (a, b), mid-latitude North Atlantic (MNA) (c, d) and tropical North Atlantic (TNA) (e, f); seasonal cycles for TCO and LTCO are shown in the first and second row respectively. The amplitude of the seasonal cycle varies in different regions, with larger seasonal changes being observed at mid latitude compared to the tropical part of the domain. Observations (black lines) show a broad maximum in spring and early summer for all three regions; this is consistent with previous studies (Logan 1985, Parrish et al., 2013) and can be attributed to two major sources of tropospheric ozone: transport from the stratosphere (with a maximum in late spring and early summer) and photochemical production from ozone precursors' emissions (with a maximum in summer).

Despite the regional biases highlighted in Figure 1, the model is generally able to reproduce observed seasonal variations in tropospheric ozone. The seasonal cycle of modelled TCO and LTCO is consistent with observations, especially at mid latitudes (Fig 2c, 2d), where the amplitude and phase of the modelled and observed seasonal cycles are in good agreement. However, UKCA TCO shows an additional seasonal maximum in the tropical North Atlantic in late summer which is not present in the observations (Fig 2e). This late summer discrepancy is less marked for LTCO (Fig 2f).

Seasonal maps, shown in supplementary Figure 2 (SF 2) can help identify the regions linked to the seasonal maxima in Figure 2. In SF 2a, the observed summer maximum in TCO is centred around $30^{\circ} \mathrm{N}: 40^{\circ} \mathrm{N}$; in contrast, the modelled summer TCO (SF 2c) exhibits an additional maximum over Northern Africa and parts of the tropical Atlantic Ocean. The observed TCO maximum between $30^{\circ} \mathrm{N}: 40^{\circ} \mathrm{N}$ in spring is consistent with Stratosphere to Troposphere Transport (STT) of ozone, 285 which typically occurs around $30^{\circ} \mathrm{N}$ in the spring and early summer (Skerlak et al., 2014).

From the analysis of Figure 1, Figure 2 and supplementary Figure 2, it appears that modelled LTCO is in generally good agreement with observations, whilst modelled TCO exhibits a large positive bias and an additional seasonal maximum in late summer compared to observations, with both discrepancies occurring over the tropical North Atlantic and Northern Africa. These results are not unexpected: recent UKCA model evaluations found a widespread TCO positive bias across most of the 290 Tropics (Archibald et al, 2020b; Robson et al., 2020) and this bias is mostly unchanged when a more complex chemistry scheme is used (Archer-Nichols et al., 2021). UKCA is also not unique in exhibiting a TCO bias with respect to OMI-MLS: GFDL AM4.1 (Horowitz et al., 2020) has a widespread positive bias in the Tropics which is in excess of $20 \%$ over Africa and South America. 
https://doi.org/10.5194/acp-2022-99

Preprint. Discussion started: 2 March 2022

(c) Author(s) 2022. CC BY 4.0 License.

(c) (i)

a)

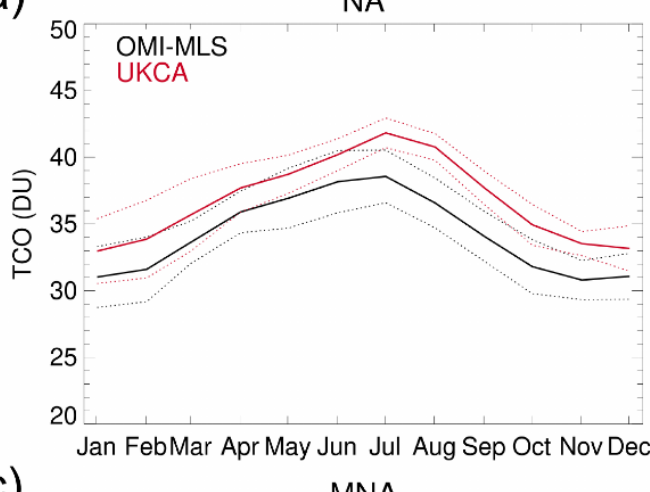

c)

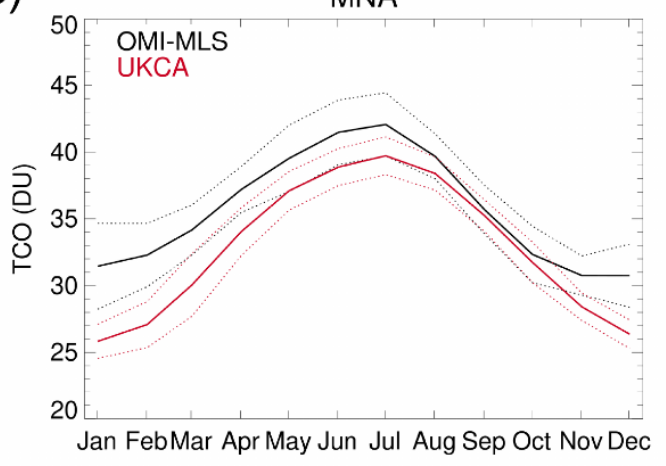

e)

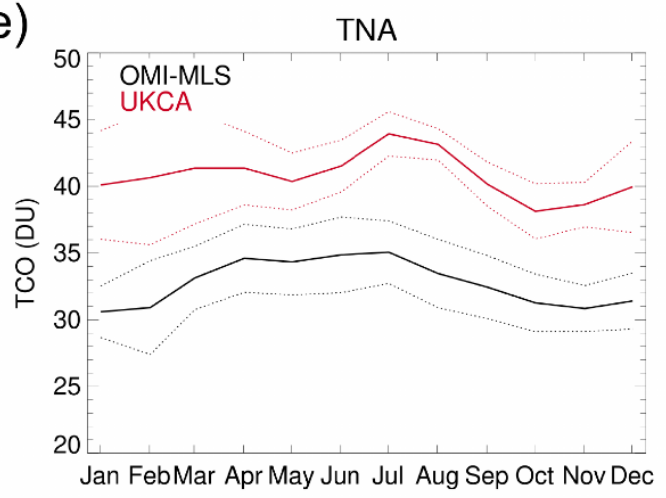

b)

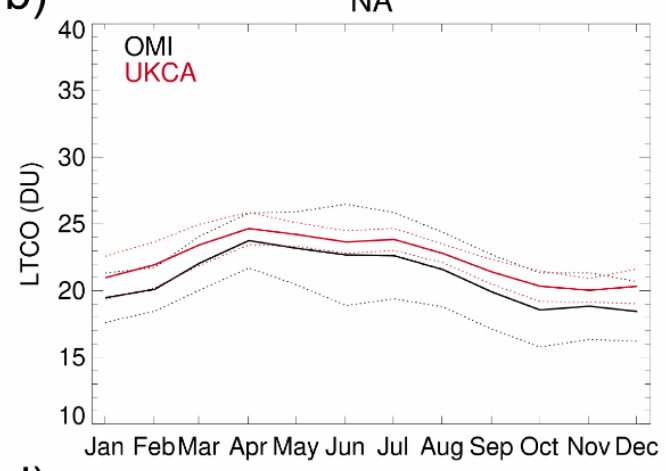

d)

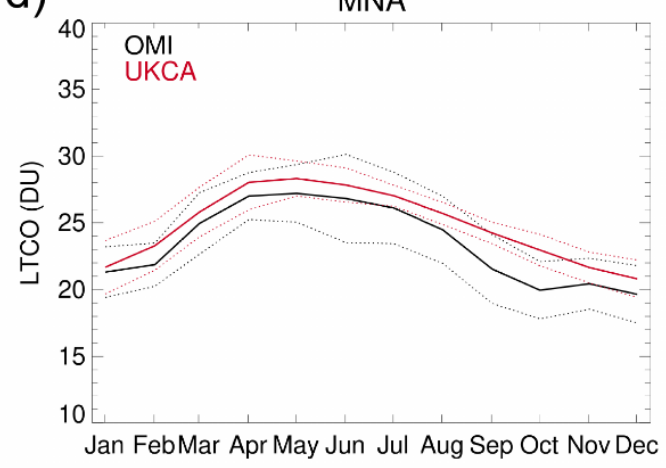

f)

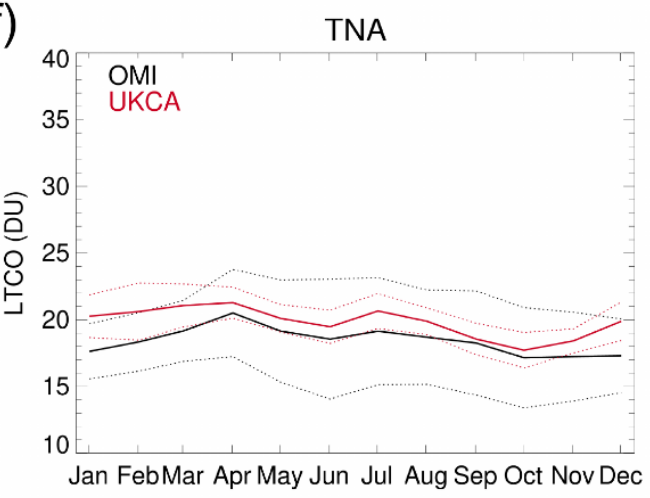

295 Figure 2: Tropospheric ozone seasonal cycle averaged over the North Atlantic (a, b), mid-latitude North Atlantic (c, d) and tropical North Atlantic (e, f). First column shows TCO and second column shows LTCO. Dotted lines indicate the 2 standard deviation interval.

Furthermore, there is also some uncertainty in TCO measurements, which is reflected in the spread of values from different satellite platforms: Gaudel et al. (2018) reported average annual TCO values from 5 different satellite datasets ranging between $\sim 25-35 \mathrm{DU}$ for the latitude band $0^{\circ}: 30^{\circ} \mathrm{N}$ and the period from 2005 to 2016. Despite this spread in the observed 
TCO values, UKCA TCO, calculated for the same latitude band and period described in Gaudel (2018), shows values in the range 35-39DU, which are outside the range of uncertainty of the combined observations. On the other hand, UKCA's ozone burden in the $60^{\circ} \mathrm{S}: 60^{\circ} \mathrm{N}$ range shows a very good agreement with observations: Gaudel (2018) reported a mean ozone burden, from 5 satellite datasets between $60^{\circ} \mathrm{S}: 60^{\circ} \mathrm{N}$, of $\sim 300 \mathrm{Tg}+/-6 \%$ for the most recent satellite record (up to 2016). In our study the tropospheric ozone burden from OMI-MLS and UKCA for the 2005-2018 period are 297 and $301 \mathrm{Tg}$ respectively. Archibald et al. (2020b) have shown that the UKCA global tropospheric ozone burden is consistent with observations as a result of an overestimate of TCO in the Tropics and an underestimate of TCO at mid latitudes, which is in line with our findings.

One well known issue when using TCO to evaluate modelled tropospheric ozone is that small differences in tropopause definition can lead to large differences in TCO due to the strong ozone gradient around the tropopause. OMI-MLS data uses the WMO lapse rate tropopause, calculated from NCEP reanalysis, to estimate tropopause pressure and define TCO (Ziemke et al., 2006). The first step is therefore to ascertain whether the modelled positive bias is real and not an artifact of different tropopause definitions being used for the calculation of the tropospheric column in the modelled and observed TCO. Supplementary Figure 3 (SF 3) shows three modelled TCOs, and their respective bias relative to OMI-MLS, calculated for

315 three different tropopause definitions, including the 125ppb ozonopause and the WMO lapse rate. The modelled TCO varies with different tropopause definitions (similarly to the findings in Griffiths et al., 2021) but the large positive bias in the Tropics remains a common feature despite the different tropopause definitions. We can therefore conclude that the modelled positive bias in the tropical North Atlantic is larger than the uncertainty arising from the choice of tropopause used in the calculation of the TCO.

320 Modelled LTCO shows a smaller bias and a better seasonal agreement with observed OMI data; this could be either because the model bias is smaller in the lower troposphere or because averaging kernels and a priori information from the OMI data were used to construct modelled LTCO, hence increasing the model's ability to reproduce observations by using the same vertical sampling and cloud screening as the satellite data (Williams et al., 2019). In order to discern between these two possibilities, we compare the modelled and OMI subcolumns between 450-170 hPa. This retrieved subcolumn is most sensitive to heights between $\sim 6-13 \mathrm{~km}$ which, for tropical latitudes, is below the tropopause. Figure 3 shows a comparison of observed and modelled ozone subcolumns for $\sim 450-170 \mathrm{hPa}$ in the Tropical North Atlantic; despite the use of satellite AK and a priori information, the model shows a large positive bias in the tropical upper troposphere. The bias is largest over subequatorial Africa, and differences are larger than 6 DU (Fig 3c) or $\sim 60 \%$ (Fig 3d) for a large part of the tropical domain; this is consistent with the TCO bias shown in Figure 1e and 1g. Use of the OMI data for different vertical layers allows us to recognise that the model TCO bias in the tropical North Atlantic results from a large positive bias in the tropical upper troposphere and a smaller bias in the tropical lower troposphere. The tropical bias in UKCA is not restricted to the North Atlantic (Archibald et al., 2020b; Archer-Nichols et al., 2021). An extension to the global scale is shown in supplementary Figure 4: top row provides a comparison between zonally averaged ozone vertical profiles from UKCA and the Bodeker Scientific Vertical Ozone dataset (Hassler et al., 2018); middle and bottom row show global multiannual mean maps of 
https://doi.org/10.5194/acp-2022-99

Preprint. Discussion started: 2 March 2022

(c) Author(s) 2022. CC BY 4.0 License.

(c) (i)

335 differences between modelled and observed ozone in the three separate columns (LTCO, UTCO and TCO), confirming that the model bias extends over a large geographical region of the tropical upper troposphere.
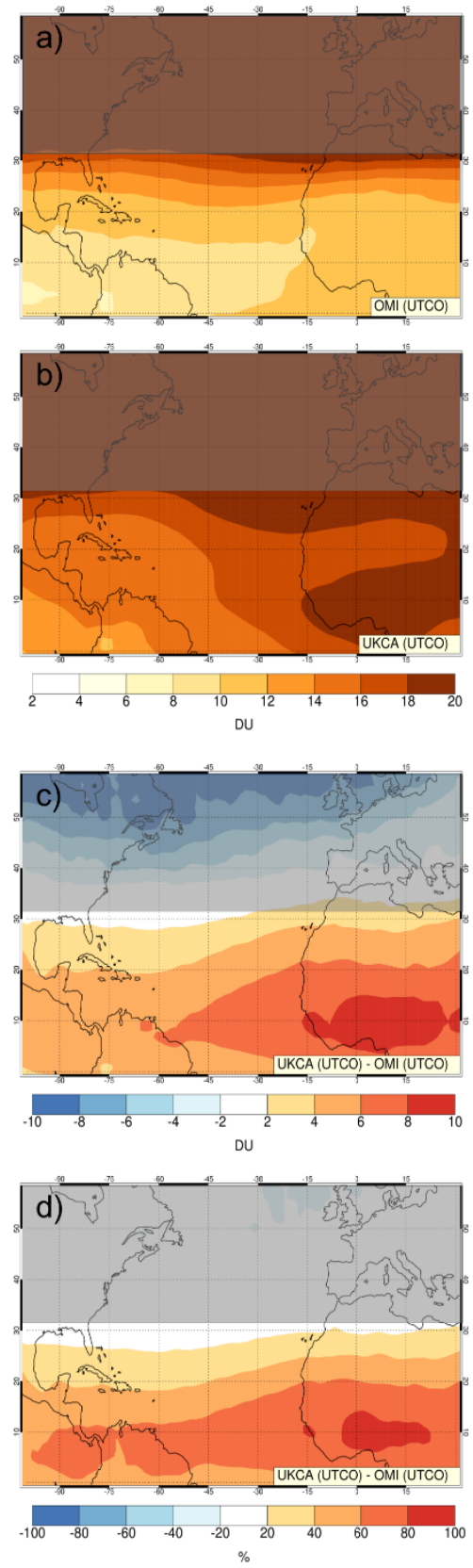

Figure 3: Upper tropospheric ozone column (450-170 hPa) multiannual means for the period 2005-2018. a) OMI UTCO; b) UKCA UTCO; c) difference between modelled and observed UTCO (DU); d) same as c but expressed as a percentage difference. 340 Latitudes outside the Tropics are shaded since this ozone subcolumn at mid latitudes samples the lower stratosphere as well as the upper troposphere. 
Whilst the modelled tropical bias is supported by the comparison with the BS vertical ozone dataset (SF $4 \mathrm{~b}$ ), with largest differences in the tropical upper troposphere, the modelled vertical profiles are in generally good agreement with BS observations in the northern and southern mid latitudes ( $\mathrm{SF} 4 \mathrm{a}$ and $\mathrm{c}$ ), therefore leaving some questions on the modelled TCO negative bias at southern mid-latitudes relative to OMI-MLS (see SF $4 \mathrm{f}$, i). We have shown that when satellite operators are used to correctly sample model data there is generally a good agreement between UKCA and OMI ozone in the lower troposphere (Fig $1 \mathrm{f}, \mathrm{h}$ and SF $4 \mathrm{~d}, \mathrm{~g}$ ); however, when no operators are used to correct for vertical sampling, a negative bias (similar in magnitude to the TCO bias) is detected for the modelled lower tropospheric ozone at mid and high latitudes due to stratospheric influence on the observations (not shown). It is possible that the modelled TCO negative bias at southern mid and high -latitudes and northern high-latitudes relative to OMI-MLS, might also be the result of inconsistent sampling between model and observations due to the lack of satellite operators for this observational dataset.

\subsection{Sources of uncertainty for modelled tropospheric ozone in the North Atlantic basin.}

355 Having established that the model bias is greatest in the tropical upper troposphere we now focus on possible reasons for such discrepancy. Ozone precursor gases can be emitted from both anthropogenic and natural sources. Present day anthropogenic emissions are generally well constrained, and their geographical locations, seasonal variations and magnitudes are derived from emission inventories and inverse modelling techniques (Lamarque et al., 2010; Feng et al., 2020). In contrast, some natural emissions of ozone precursors have quite large uncertainties; these include CO from biomass burning, biogenic isoprene and NOx from lightning. An overestimate of such ozone precursors emissions in the model could therefore result in an overestimate of tropospheric ozone.

Biomass burning emissions and biogenic emissions of isoprene are responsible for a large part of VOC emissions in the Tropics. The largest source of biomass burning in the North Atlantic is from equatorial Africa (between 0:15N); these emissions have a marked seasonal maximum in winter (Roberts et al., 2009, van der Werf et al., 2017) and a large interannual variability. However, model sensitivity experiments showed that completely removing biomass burning emissions from the model input has a very small impact on the tropospheric ozone budget, with maximum differences of 2DU in August (Shin, personal communication); this suggests that whilst biomass burning emissions might be important on the local scale, they do not have a large impact on tropospheric ozone at the regional and global scale in UKCA.

Isoprene emissions are largest in equatorial Africa, South America and South East Asia; in UKCA these emissions are produced interactively and are diagnosed from the gross primary productivity of the terrestrial vegetation (Arneth et al., 2007; Pacifico et al., 2011). Present day global isoprene emissions range from $\sim 500$ to $750 \mathrm{Tg} \mathrm{yr}-1$ (Achakulwisut et al., 2015). The way isoprene affects ozone concentrations throughout the troposphere is complex and several studies have focused on the effect of isoprene emissions on tropospheric ozone (Paulot et al., 2012; Squire et al., 2015; Hollaway et al., 2016; Weber et al., 2021). Hollaway et al. showed that a reduction of $\sim 100 \mathrm{Tg}$ in isoprene emissions results in a reduction in zonal mean ozone concentrations, with largest difference $(\sim 2 \mathrm{ppbv})$ in the tropical upper troposphere. However, the relative 
impact of isoprene on ozone is highly dependent on the chemical scheme used to describe isoprene oxidation and reactivity (Squire et al., 2015, Weber et al., 2021). Further uncertainty in the modelled seasonality and geographical distribution of isoprene emissions could also lead to a discrepancy between modelled and observed ozone.

Another possible source of model uncertainty is NOx emissions from lightning (LiNOx). Lightning flashes are most frequent in the Tropics, and are linked to deep convective storms over Africa, South America and South East Asia. LiNOx emissions in UKCA are parameterised (based on Price and Rind, 1992) and released partly at the surface but mostly within the depth of convective clouds; as a result, LiNOx emissions are largest in the tropical upper troposphere. The estimated range of NOx emissions from lightning varies between 2-8 $\operatorname{Tg}(\mathrm{N}) \mathrm{yr}^{-1}$ (Shuman and Huntrieser 2007, Wang et al., 2013), 4-8 $\operatorname{Tg}(\mathrm{N}) \mathrm{yr}^{-1}$ (Martin et al., 2007) and more recent estimates of $9 \mathrm{Tg}(\mathrm{N}) \mathrm{yr}^{-1}$ (Nault et al., 2017). Although NOx from lightning represents 385 a small fraction of total NOx emissions, with $\sim 20.5 \mathrm{Tg}(\mathrm{N}) \mathrm{yr}^{-1}$ coming from anthropogenic sources and $\sim 5.5 \mathrm{Tg}(\mathrm{N}) \mathrm{yr}^{-1}$ from biomass burning (Lamarque et al., 2010), it has a disproportionately large influence on the tropospheric ozone budget. This is because ozone production efficiencies per unit NOx are an order of magnitude higher in the tropical upper troposphere (Pickering et al., 1990). It has been estimated that a reduction in LiNOx from 5 to $2.5 \mathrm{Tg}(\mathrm{N}) \mathrm{yr}^{-1}$ results in a significant reduction, up to 40-60\%, in upper tropospheric ozone in the Tropics (Liaskos et al., 2015). Lelieveld and Dentener (2000) showed that the contribution of lighting to ozone in the tropical upper troposphere is $\sim 50 \%$, while Grewe (2007) used tagged tracers from different NOx sources and found lightning contributed $70 \%$ of NOy and $40 \%$ of ozone in the tropical upper troposphere. LiNOx parameterisation is therefore a potentially large source of uncertainty in UKCA tropospheric ozone budget. 

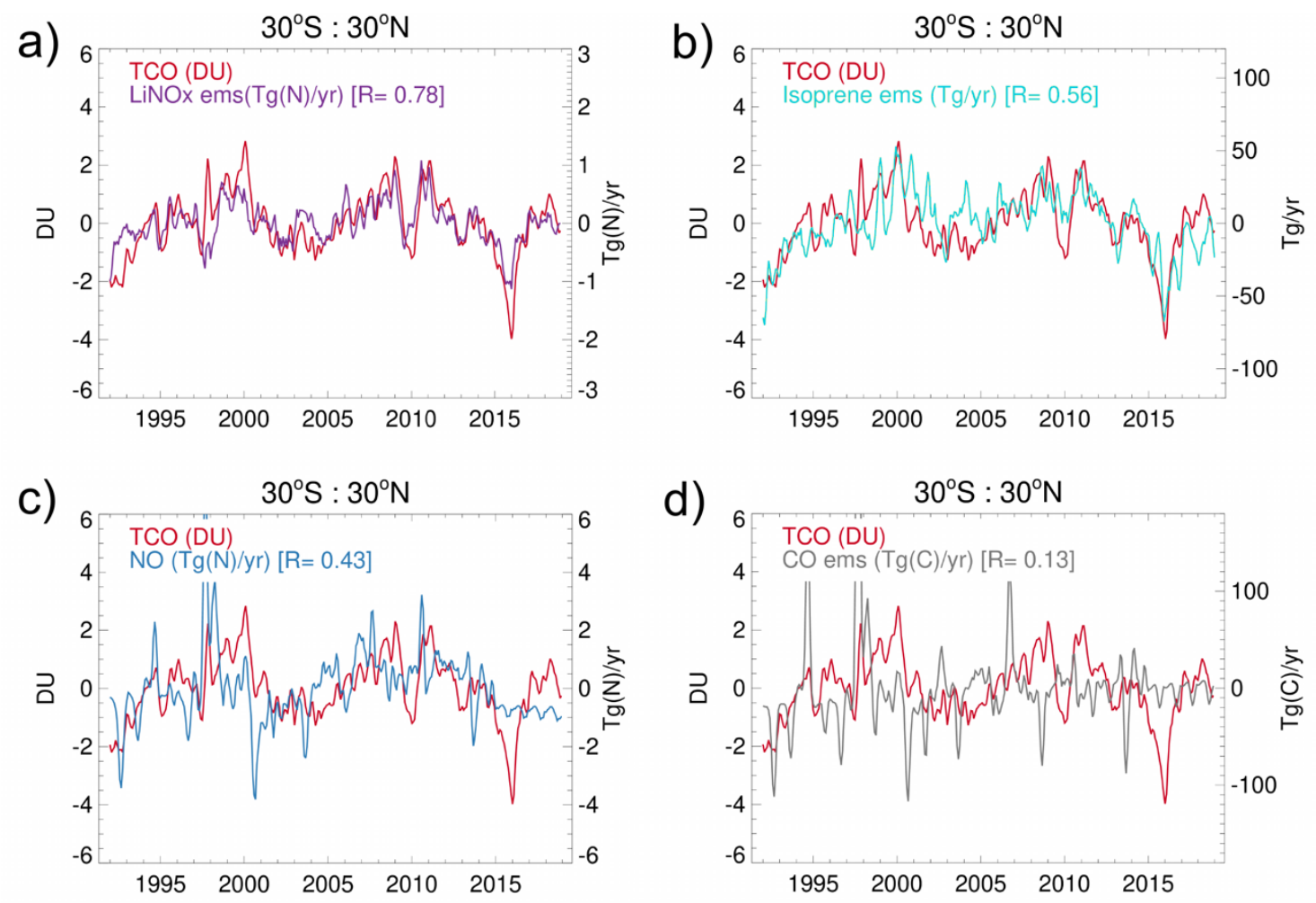

Figure 4: Deseasonalised and detrended timeseries anomalies showing Pearson's correlation coefficient (R) calculated between timeseries of modelled TCO and emissions of ozone precursors, averaged over the Tropics, for the period 1992-2018.

To investigate the source of UKCA tropical ozone bias we look at the temporal evolution of modelled TCO and modelled ozone precursor emissions over the period of the model integration (1992-2018). One way to understand how modelled TCO changes in response to changes in modelled emissions is to calculate the Pearson's correlation coefficient, R, and the coefficient of determination, $\mathrm{R}^{2}$, between the timeseries of ozone and specific ozone precursor emissions.

Figure 4 shows deseasonalised and detrended timeseries anomalies averaged over the tropical region for 1992-2018. In UKCA, tropical TCO is strongly correlated $(\mathrm{R}=0.78)$ to LiNOx emissions (Fig $4 \mathrm{a}$ ), which explain $\sim 60 \%$ of the modelled ozone interannual variability $\left(\mathrm{R}^{2}=0.61\right.$ ); in contrast, surface NOx emissions (Fig 4c) have a relatively lower correlation to TCO $(\mathrm{R}=0.43)$ and about $\sim 20 \%$ of tropical TCO variability can be attributed to changes in surface NOx $\left(\mathrm{R}^{2}=0.18\right)$. Amongst possible sources of VOC in the tropics, isoprene emissions (Fig 4b) have a higher correlation to TCO than CO emissions (Fig 4d). This suggests that the main production of ozone in the tropical troposphere occurs via reaction of LiNOx with isoprene and other long lived hydrocarbons and is less sensitive to surface NOx emissions and CO emissions. As mentioned 410 before, both LiNOx and isoprene emissions are calculated interactively in UKCA, therefore, given the high correlation with modelled ozone in the Tropics, errors in the geographical distribution, seasonality or magnitude of such emissions will play a 
key role in how accurately tropical TCO is represented in the model. The sensitivity of modelled TCO to changes in the magnitude of LiNOx and isoprene emissions was further investigated through a number of sensitivity experiments (see supplementary Figure 5) whereby global isoprene and LiNOx emission values were modified, without changing their geographical or seasonal distributions. These confirmed that changes in LiNOx emissions have a large impact on tropical TCO: in agreement with previous studies (Liaskos et al., 2015), a reduction in LiNOx emissions of $\sim 5 \operatorname{Tg}(\mathrm{N})$ results in a marked decrease in modelled TCO over large regions in the Tropics (SF $5 b$ ) with largest difference $\sim 10-15 \mathrm{ppbv}$ in the free troposphere, between 5-13km, and smaller differences (2-5ppbv) in the lower troposphere (SF 5a). Reducing isoprene

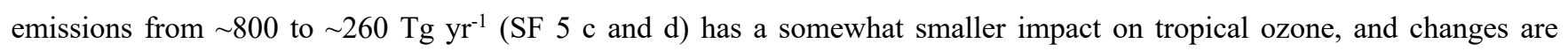
vertically more homogeneous ( $\sim 2-5 \mathrm{ppbv}$ throughout the depth of the troposphere). In this context, it is worth mentioning that a more complete chemistry scheme, which includes isoprene peroxy radicals H-shifts and HOx recycling, has been developed and tested in UKCA (Weber et al., 2021) and could lead to a different sensitivity of modelled tropospheric ozone to isoprene emissions.

Both temporal correlation analysis (Fig 4) and sensitivity experiments (SF 5) point to LiNOx emissions as a major source of modelled TCO bias in the tropical upper troposphere.

\subsection{Observed vs modelled lightning flash rate.}

In order to understand where the model inaccuracy in the LiNOx emissions stems from, we compare observed and modelled climatology of lightning flashes for 1996-2013 (chosen as the period for which LIS-OTD flash rate observations are available). Figure 5 shows multiannual mean maps of observed (a) and modelled (b) lightning flash rates, while supplementary Figure 6 shows the same comparison but using seasonally averaged maps. This analysis shows that: i) the model underestimates lightning flashes globally (with $7.8 * 10^{10}$ flashes per year on average between 1996-2013, compared to $15.3^{*} 10^{10}$ from LIS-OTD); ii) the model underestimates the seasonal increase in lightning activity for the summer hemisphere; iii) the model overestimates flashes in the Tropics compared to mid latitudes; iv) the model overestimates flashes over land compared to the ocean. Although the latter point has been addressed by a recent modification in the UKCA lightning flashes parameterisation (Luhar et al., 2020), the modelled overestimate of flashes in the Tropics and underestimate at mid latitudes is still an issue (see Fig 4 in Luhar et al., 2020). These model shortfalls in the geographical distribution and seasonality of lightning flashes are interlinked and mainly stem from the use of cloud diagnostics from the convection parameterisation scheme being used to estimate cloud thickness in the lightning scheme. This is because deep convection in the model is nearly totally restricted to tropical regions resulting in a large fraction of extra tropical convective storms and their seasonal shift to higher latitudes being underestimated, leading to an imbalance between tropical and extra tropical lightning flashes. In fact, a lightning flash parameterisation based on cloud ice flux (Finney et al., 2014) was shown to have a much better zonal distribution of flashes compared to observations. 

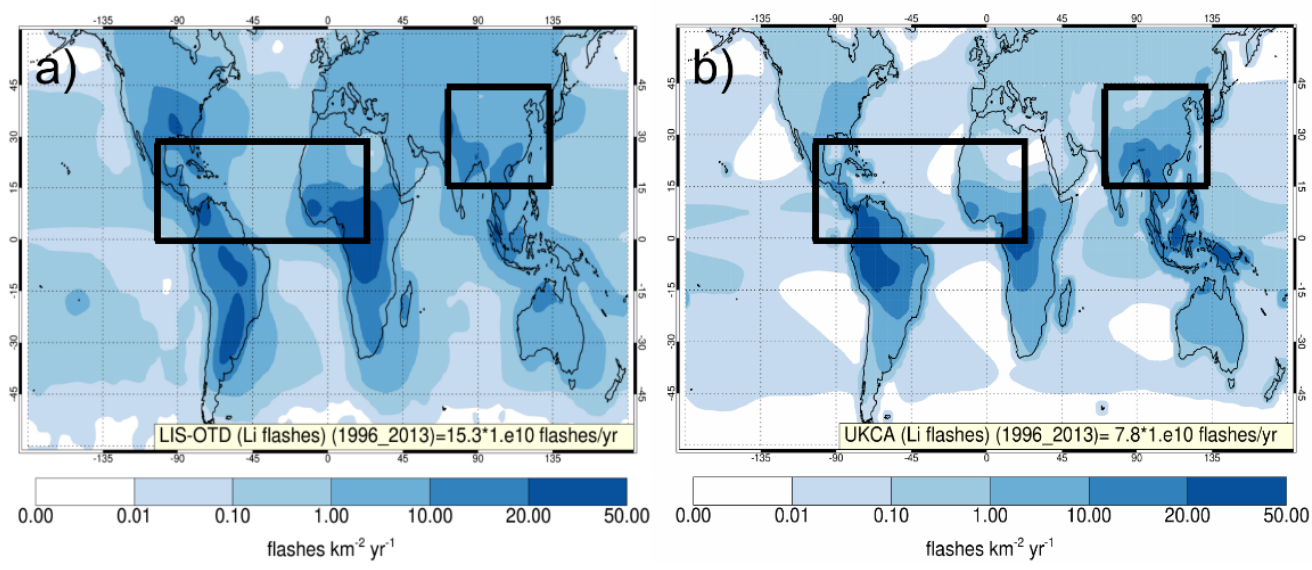

c)

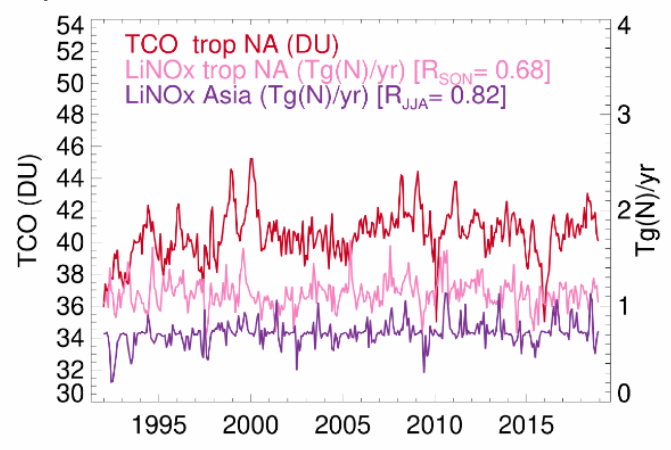

d)

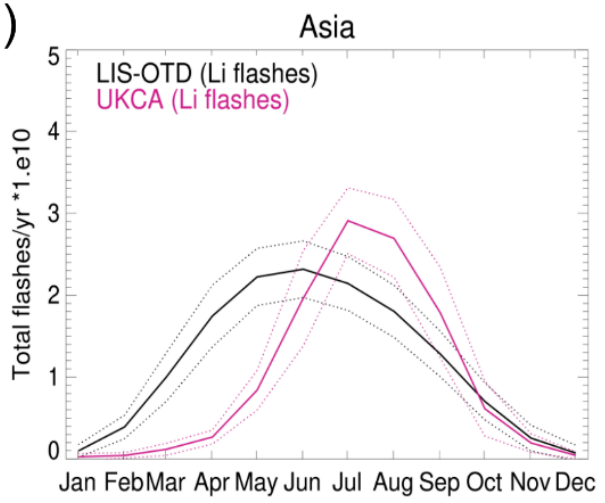

445 Figure 5: Comparison of observed (a) and modelled (b) multiannual mean maps of lightning flash rates for 1996-2013; black boxes indicate tropical North Atlantic and Asia. Panel c) shows deseasonalised and detrended timeseries of TCO in the tropical North Atlantic and regional LiNOx emissions: large seasonal correlations were found for tropical North Atlantic TCO and LiNOx from tropical North Atlantic and Asia ( $R$ values are shown in the legend for seasons with largest correlation). Panel d) shows observed and modelled seasonal cycle of lightning flashes for the period 1996-2013 over Asia.

Another issue in this lightning NOx parameterisation is that, in order to ensure the modelled global LiNOx emissions fall within the estimated range, a scaling factor is used to prescribe the amount of LiNOx emitted per flash. As a result, a relatively small number of modelled flashes, mostly concentrated in the Tropics, will yield the entirety of the global emissions of LiNOx leading to an overestimate in LiNOx, and consequent widespread ozone bias, in the tropical upper troposphere. The model underestimate of flashes and LiNOx emissions outside the Tropics could also potentially contribute to an underestimate of tropospheric ozone at mid latitudes.

We now address more specifically the way that errors in modelled LiNOx emissions affect modelled tropospheric ozone in the North Atlantic. Similarly to our approach in Figure 4a, we investigate how modelled TCO, this time in the tropical North Atlantic, correlates to LiNOx emissions from a number of source regions and seasons. Note that due to the strongly seasonal 
nature of regional LiNOx emissions (see also supplementary Figure 6), correlation coefficients are calculated only for the seasons with the largest regional emissions (JJA for East Asia and SON for the tropical north Atlantic). This analysis (summarised in Figure 5c) reveals that TCO in the tropical North Atlantic has a sizeable correlation with local LiNOx emissions (with largest Rson value of 0.68 in the autumn) but an even stronger correlation with LiNOx emissions from South East Asia (defined as the region delimited by the box in Figure $5 \mathrm{a}$ and $5 \mathrm{~b}$ ) in the summer $\left(\mathrm{R}_{\mathrm{JJA}}=0.82\right.$ ), explaining $\sim 70 \%$ of its summer variability $\left(\mathrm{RJJA}^{2}=0.67\right.$ ). This is consistent with modelled ozone, produced from LiNOx over East Asia in summer, being efficiently transported to the tropical North Atlantic by the prevailing North-easterly trade winds. Over Asia, modelled lightning flashes have a pronounced summer maximum (Fig 5d), whilst observed lightning flashes display a broader maximum across spring and summer (see Figure 5d and supplementary Figure 6). This discrepancy in the seasonality of LiNOx emissions over Asia could be responsible for modelled TCO in the tropical North Atlantic having a stronger summer maximum compared to observations (Fig 2e).

\section{Time evolution of Tropospheric ozone: interannual and decadal variability.}

We now investigate how tropospheric ozone in the North Atlantic has been changing over time, with a focus on the recent past (2005-2018). Tropospheric ozone has a large seasonal cycle, particularly at mid latitudes (as shown in Fig 2), therefore in order to investigate the interannual and decadal variability of tropospheric ozone in the North Atlantic the seasonal signal has been removed from the observed and modelled ozone data. In a recent paper, Archibald et al. (2020a) have shown that modelled tropospheric ozone has been increasing sharply throughout the early 1900s and then more slowly from the 1960s to present day. They postulate that this is consistent with a strong increase in anthropogenic ozone precursors emissions during most of the 1900s and showed that tropospheric ozone chemical production peaked in the 1990s and has been slowly decreasing after that, as anthropogenic NOx emissions have been levelling off. This suggests that emissions from non anthropogenic sources and transport of ozone from the stratosphere are likely to play a major role on the interannual and decadal variability of tropospheric ozone from 2000s onward. In this section we aim to investigate recent interannual and decadal variability of tropospheric ozone in the North Atlantic and the drivers of such variability.

\subsection{Observed vs modelled tropospheric ozone interannual variability and trends in the North Atlantic}

485 Figure 6 shows a comparison between observed and modelled time evolution of TCO (first column) and LTCO (second column); these are plotted as deseasonalised timeseries anomalies, averaged over the North Atlantic (top row), mid latitude North Atlantic (middle row) and tropical North Atlantic (bottom row). The observed timeseries indicate ozone remained constant or slightly decreased between 2005 and 2010, followed by an increase and, in the case of OMI LTCO, a further decrease from 2014-2016 onwards. This highlights that ozone changes in the North Atlantic are not constant over time and

490 therefore trends can be very different depending on the period used to calculate them. Several different approaches have been used in the literature to estimate ozone trends, ranging from fairly complex, such as 'multivariate linear regression' (Ziemke et al., 1997, 2019) to simple linear regression fit (e.g. Gaudel et al., 2018). In this work we chose a simple linear regression 
method since our aim is to compare differences between modelled and observed trends, rather than provide the most accurate estimate of ozone trends between 2005 and 2018. The linear trends and errors over this period are noted in the legends in

495 Figure 6: both satellite datasets show positive values in the tropical part of the domain (1.6-1.7 DU decade ${ }^{-1}$, equivalent to $\sim 5$ $\%$ per decade for TCO and $\sim 10 \%$ per decade for LTCO). These are relatively large trends, which are comparable in magnitude to modelled trends for the early part of the $20^{\text {th }}$ century, when anthropogenic emissions of ozone precursors were increasing significantly.

While trends for the two observed datasets agree well over the tropical part of the domain, OMI-MLS trends are larger in the mid latitude North Atlantic compared to OMI, which shows a zero trend within the estimated error. These findings are consistent with previous studies (Gaudel et al., 2018), which found generally positive ozone trends in the recent past (over period ranging between 1996 and 2016, depending on the specific datasets) and a large spread in trends estimated from different satellite platforms. With the exception of two satellite datasets, whose record started in 2008 and showed small negative trends, Gaudel et al. (2018) found positive linear trends in TCO for most other datasets over the northern 505 hemisphere to be between 1.7 and $2.7 \mathrm{DU}_{\text {decade }}{ }^{-1}$. In contrast to observed trends, UKCA ozone trends tend to be much smaller in magnitude and effectively zero (within the error) for both the tropical and mid latitude part of the domain. Figure 6 can also give an insight on the interannual variability of tropospheric ozone: the temporal correlation between observed and modelled timeseries in Figure 6 is generally low (ranging between 0 and 0.25 for the different domains and subcolumns) suggesting that the factors driving interannual variability might be different for observed and modelled tropospheric ozone 510 (see section 4.2 and 4.3 for further discussion on drivers of North Atlantic ozone interannual variability). 
https://doi.org/10.5194/acp-2022-99

Preprint. Discussion started: 2 March 2022

(c) Author(s) 2022. CC BY 4.0 License.

(c) (i)

a)

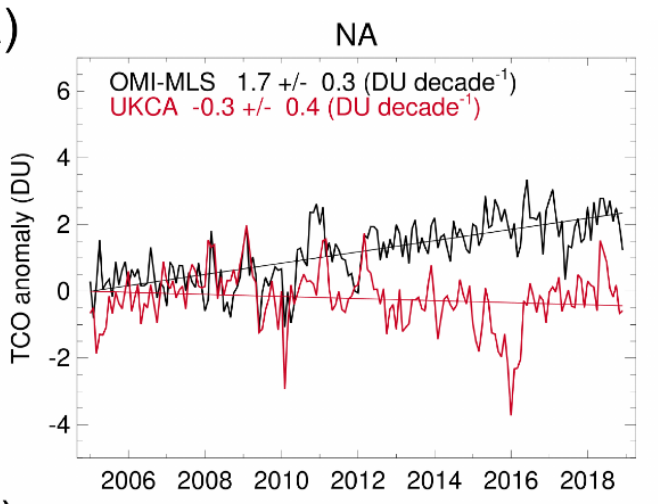

c)

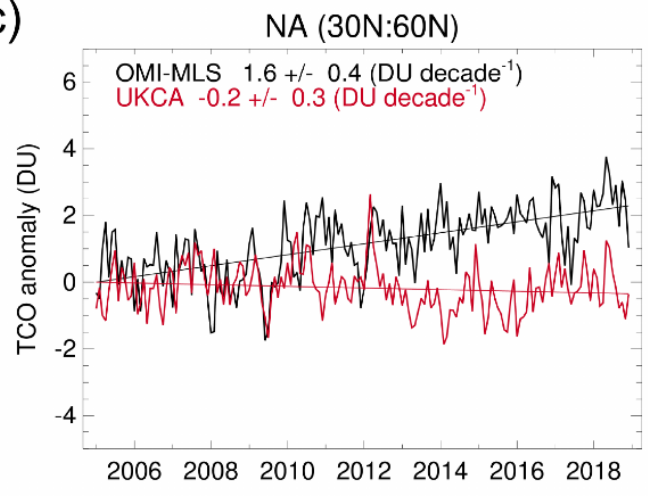

e)

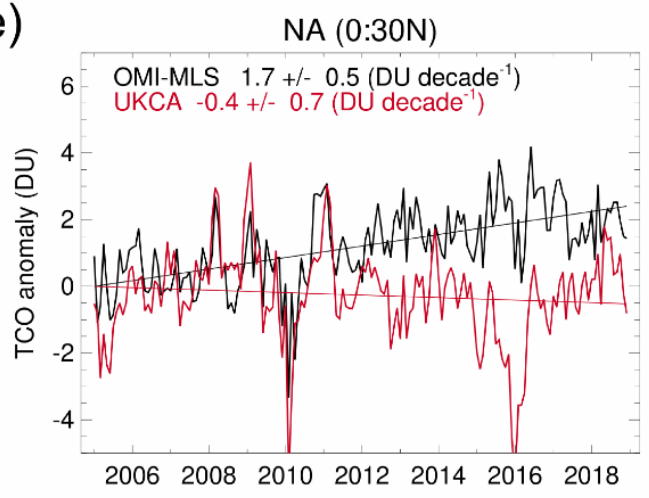

b)

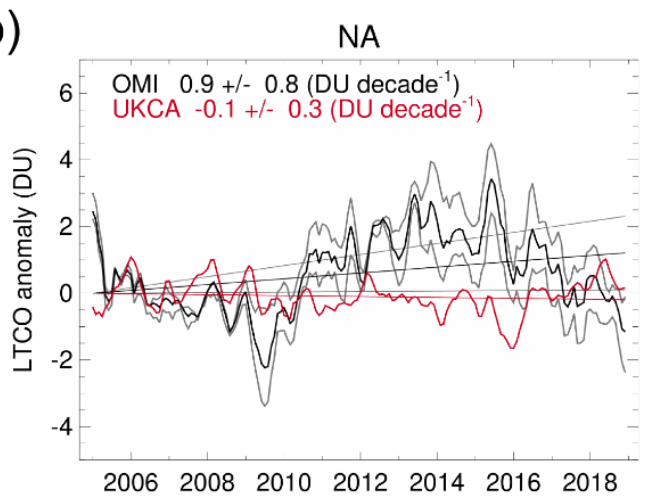

d)

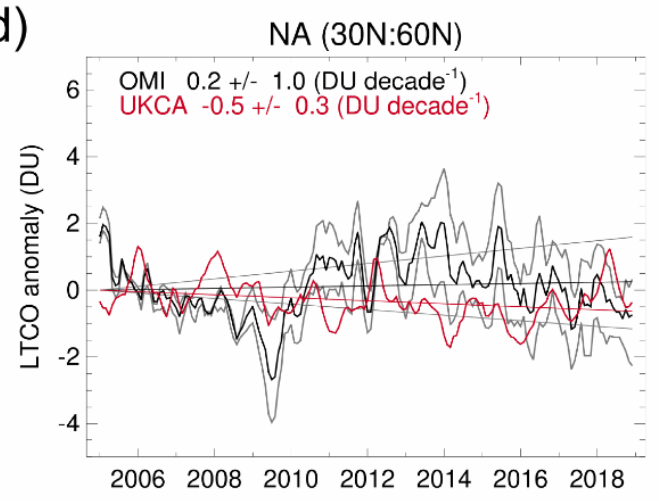

f)

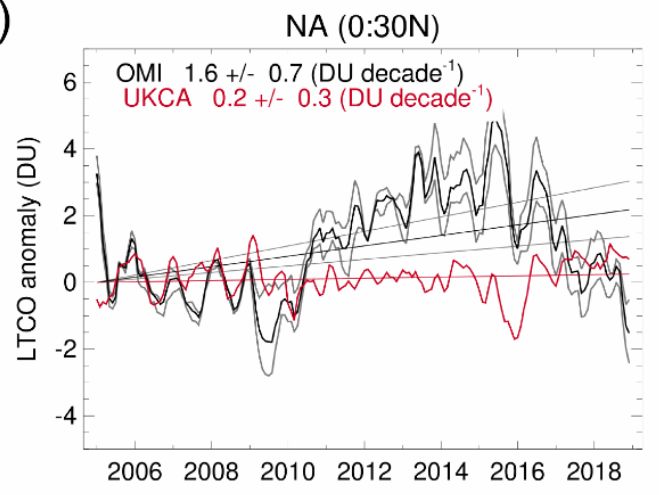

Figure 6: Tropospheric ozone deseasonalised timeseries over the North Atlantic (a, b), mid-latitude North Atlantic (c, d) and tropical North Atlantic (e, f). First column shows TCO and second column shows LTCO. Trends were calculated using a least square linear regression method on monthly, deseasonalised timeseries. Grey lines in panels $b, d$ and $f$, represent uncertainties associated with changes in OMI cross-track sampling. This uncertainty is largest at Northern mid latitudes and increases over time.

Another way to compare differences in the geographical distribution of observed and modelled trends is through the use of linear trend maps; Figure 7 shows observed (top row) and modelled (bottom row) tropospheric ozone trends for TCO (first 
column) and LTCO (second column); the same information for the global scale is provided in supplementary Figure 7. Despite differences in the methods used to calculate trends, the observed TCO values are consistent with previous studies (Ziemke et al., 2019, Gaudel et al, 2018). Although OMI data was previously used to calculate TCO trends by extrapolating LTCO to TCO, assuming volume mixing ratios in the lower troposphere to apply up to the tropopause (Gaudel et al., 2018), this is the first time that OMI data was used to calculate trends in LTCO. Since changes in tropospheric ozone in the past couple of decades are small relative to its interannual variability (Archibald et al., 2020a; Gaudel et al., 2018), accurately estimating such trends is a challenge both from a modelling and observational perspective and continuing remote sensing observations programs are therefore vital to provide a long-term observational record and allow for more accurate ozone trend estimates.
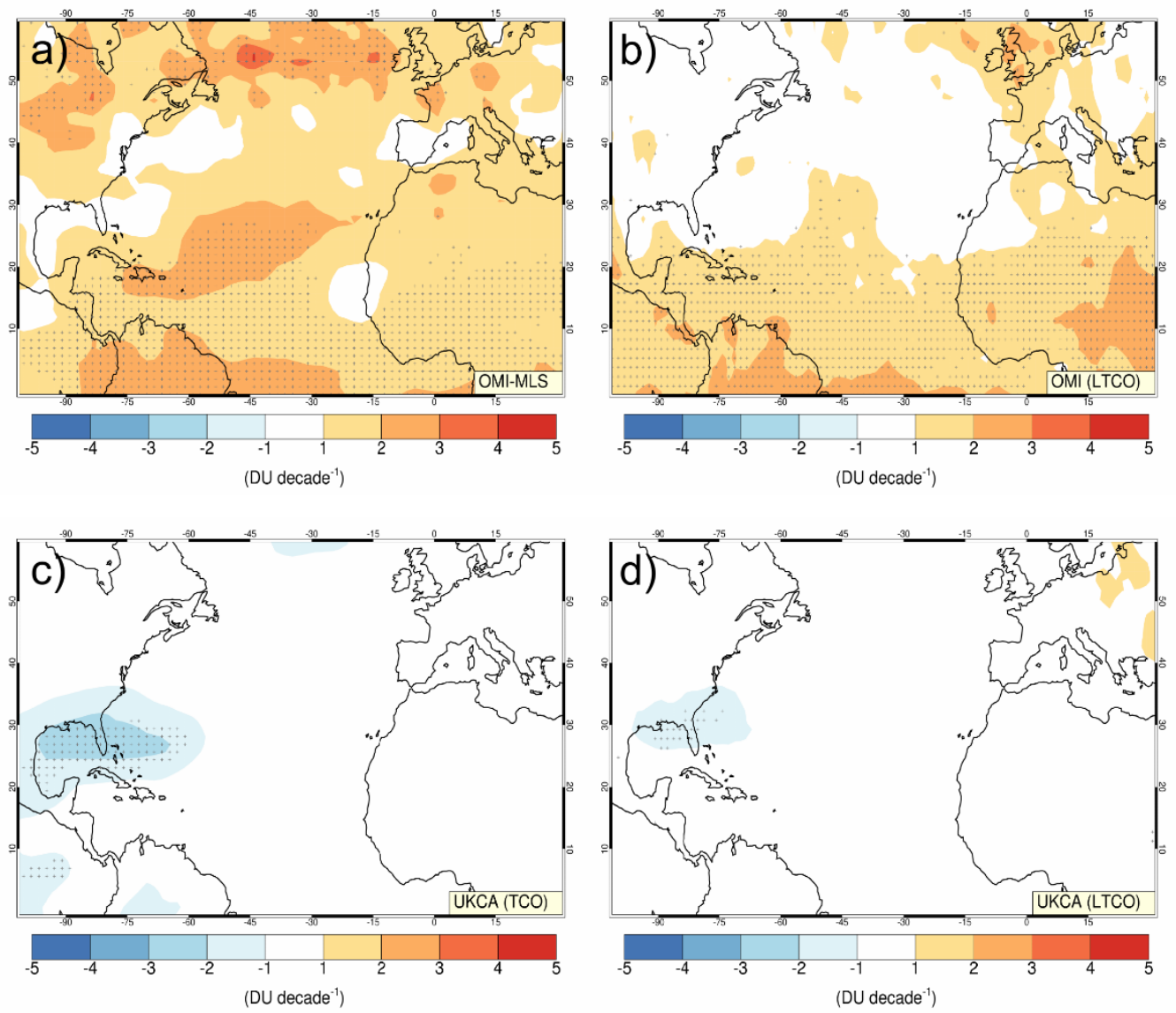

Figure 7: Tropospheric ozone trends for the period 2005-2018. OMI-MLS TCO trend (a); OMI LTCO trend (b); UKCA TCO trend (c) and UKCA LTCO trend (d). The stippling indicates where trends are significant to the $95 \%$ confidence level, based on the standard error of the residuals. 


\subsection{Drivers of North Atlantic ozone interannual and decadal variability in UKCA}

In this section we address what drives interannual and decadal variability of ozone in UKCA, with a view to understanding the reasons for the discrepancies between observed and modelled tropospheric ozone trends and interannual variability in the North Atlantic. In Figure 4 we used deseasonalised and detrended timeseries anomalies to show that modelled interannual variability of tropospheric ozone in the tropics is largely driven by changes in LiNOx emissions. Here we perform a similar analysis for the North Atlantic region. We calculate correlation coefficients between deseasonalised and detrended timeseries of TCO in the North Atlantic (for 1992-2018) and various possible ozone drivers including ozone precursors emissions and ozone transported from the stratosphere (O3S tracer). The correlation coefficients are calculated between TCO in the North

545 Atlantic and ozone drivers from three different regions (North Atlantic, the northern hemisphere and the Tropics) which allows us to distinguish between local and non-local drivers of North Atlantic ozone; results are summarised in Table 1. For values of $\mathrm{R}$ greater than 0.7 , the coefficient of determination $\mathrm{R}^{2}$ is greater than $50 \%$ (meaning that $50 \%$ of the ozone variability can be attributed to that specific ozone driver); therefore, correlation coefficients in the Table greater than 0.7 are highlighted in bold. Table 1 shows that local changes in ozone transported from the stratosphere dominate the modelled IAV

550 of tropospheric ozone in the North Atlantic, with tropical emissions of LiNOx also playing a very important role. Please note that because the different sources of ozone are not independent of each other and might themselves be correlated, the $\mathrm{R}^{2}$ values from different ozone sources do not add up to one. Timeseries of key drivers and their time correlations are also shown in supplementary Figure 8.

\begin{tabular}{lccc}
\hline SOURCE & \multicolumn{3}{c}{ R between North Atlantic TCO and source (1992-2018) } \\
& NA & NH & Tropics \\
\hline LiNOx emissions & 0.15 & 0.40 & $\mathbf{0 . 7 2}$ \\
Isoprene emissions & 0.01 & 0.13 & 0.50 \\
Surf NOx emissions & -0.12 & 0.39 & 0.35 \\
Ozone from STT & $\mathbf{0 . 7 7}$ & $\mathbf{0 . 7 6}$ & 0.62 \\
\hline
\end{tabular}

555 Table 1: correlation coefficients between modelled TCO in the North Atlantic and ozone drivers in three different regions (North Atlantic, the northern hemisphere and the Tropics). Correlation coefficients higher or equal to 0.7 are highlighted in bold. All $\mathbf{R}$ values in black are significant to the $95 \%$ confidence interval.

Having identified ozone from STT and tropical LiNOx emissions as the main drivers of modelled North Atlantic ozone interannual variability, we investigate whether decadal changes in such drivers could also be responsible for modelled ozone decadal variability and trends. In order to do that, we analyse modelled trends in ozone drivers and try to assess if ozone from STT and tropical LiNOx emissions have trends which are consistent with TCO trends. For this analysis, we divide our model integration (1992-2018) into three separate periods characterised by positive, negative and zero trends in North Atlantic TCO (Fig 8) and we calculate percentage trends in modelled TCO, ozone precursors emissions and ozone 
transported from the stratosphere in each of the subperiods, which are summarised in Table 2 (for details of absolute trend

values and uncertainties see Supplementary Table 1). In the first period, all ozone drivers in the model have positive trends, leading to the strong positive trend in modelled TCO. In the second period, tropical emissions of LiNOx have a zero trend and $\mathrm{O} 3 \mathrm{~S}$ has a negative trend, which results in a negative trend in modelled TCO. In the third period LiNOx and O3S have a zero trend, resulting in a zero trend in modelled TCO, despite a negative trend in tropical isoprene emissions. This suggests that modelled trends in O3S and lightning NOx emissions could be driving decadal variability in modelled North Atlantic TCO as trends in these key drivers are consistent with modelled ozone trends for three different periods in the model simulation. Although this analysis focuses on drivers of North Atlantic ozone interannual and decadal variability, results from Table 2 show that tropical emissions of lightning NOx and ozone transported from the stratosphere have a similarly large influence on modelled ozone trends in the northern hemisphere and the Tropics.
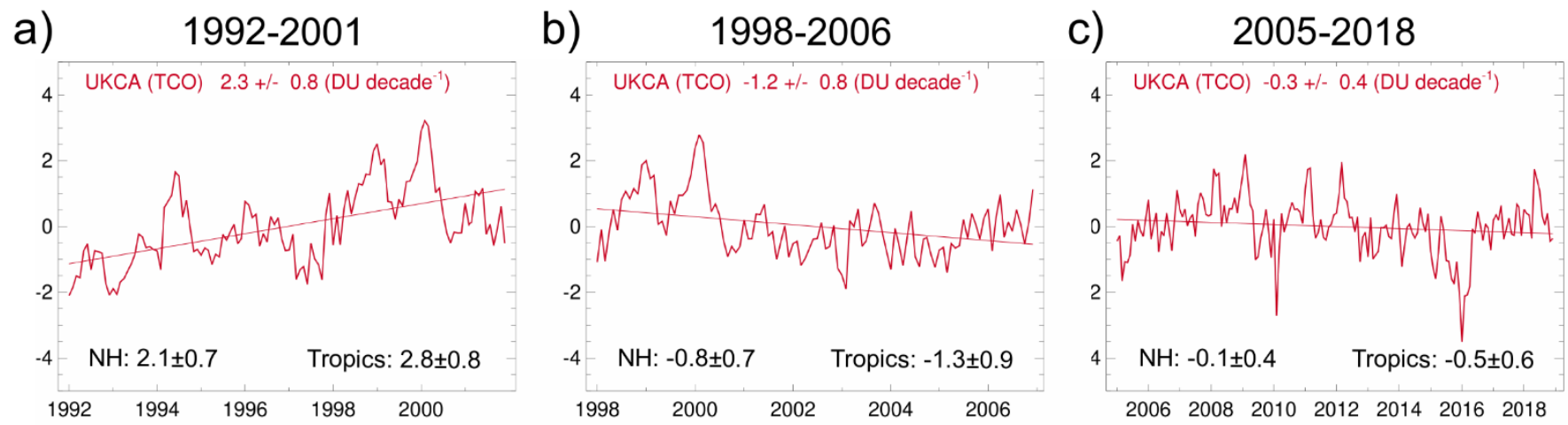

575 Figure 8: Modelled tropospheric ozone timeseries in the North Atlantic and linear trends for three different periods. Additional trends for TCO in the northern hemisphere and the Tropics are noted at the bottom of each panel.

\begin{tabular}{l|ccc|ccc|ccc}
\hline CHEMICAL FIELD & \multicolumn{3}{|c|}{$\mathbf{1 9 9 2 - 2 0 0 1}$ TREND \% } & \multicolumn{3}{c|}{ 1998-2006 TREND \% } & \multicolumn{3}{c}{ 2005-2018 TREND \% } \\
& NA & NH & Tropics & NA & NH & Tropics & NA & NH & Tropics \\
\hline UKCA TCO & 7 & 6 & 8 & -3 & -2 & -3 & 0 & 0 & 0 \\
LiNOx emissions & 0 & 0 & $\mathbf{1 7}$ & 0 & 0 & $\mathbf{0}$ & 0 & 0 & $\mathbf{0}$ \\
Isoprene emissions & -5 & 0 & 14 & 0 & 0 & 0 & -10 & -8 & -9 \\
Surf NOx emissions & 0 & 4 & 20 & -10 & 10 & 15 & -25 & 0 & 10 \\
Ozone from STT & $\mathbf{6}$ & $\mathbf{6}$ & 5 & $\mathbf{- 3}$ & $\mathbf{- 3}$ & -6 & $\mathbf{0}$ & $\mathbf{0}$ & 0 \\
\hline
\end{tabular}

Table 2: trends of modelled TCO and ozone drivers over different periods and regions (expressed as a percentage). Trends are reported as zero if they are smaller than the error of the trend estimates. Trends for species/regions having a strong correlation $(R>0.7)$ to North Atlantic TCO (see Table 1) are highlighted in bold. For details of absolute trend values and uncertainties see Supplementary Table 1. 
We now investigate reasons for the discrepancy between observed and modelled trends in the North Atlantic (for 2005-2018) rates) that lightning activity has increased in the recent past (Cecil et al., 2014; Kaplan and Lau, 2021), the model could be underestimating the trend in ozone transported from the stratosphere, leading to an underestimate of North Atlantic TCO trend compared to observations. Changes in ozone transported from the stratosphere could result from a) changes in lower stratospheric ozone concentrations or b) changes in the downward transport from the stratosphere. The latter is due to changes in the strength of the Brewer Dobson circulation (Butchart, 2014) which is intrinsically hard to evaluate as it is poorly constrained by observations. Analysis of a O3S-C model tracer (which measures modelled downward transport) shows that there has been no significant change in modelled downward transport between 2005 and 2018. We therefore investigated changes in lower stratospheric ozone concentrations using the OMI data sampled between 170-50 hPa ( 13-20 $\mathrm{km}$ ) and the equivalent UKCA data. We specifically focus on trends in modelled and observed lower stratospheric ozone in spring/autumn and around $30^{\circ} \mathrm{N} / 30^{\circ} \mathrm{S}$, which are the times and locations associated with the largest STT (Skerlak et al., 2014; Williams et al., 2019). Figure 9 shows seasonal trend maps for OMI and UKCA columns, sampled between 17050hPa: the black boxes highlight the regions and seasons most relevant for STT, whilst shaded areas indicate regions where the vertical subcolumn samples the upper troposphere as well as the lower stratosphere. From the analysis of Figure 9 we can see a clear positive trend in observed lower stratospheric ozone in the mid latitude North Atlantic in Spring that is not mirrored in the model. An additional trend analysis, using MLS lower stratospheric ozone data for 2005-2018 (not shown), is consistent with the positive OMI trends in the black boxes in Figure 9. This suggests that a lack of positive trend in spring/autumn modelled lower stratospheric ozone at mid latitudes might be responsible for the model underestimating the observed tropospheric ozone positive trends between 2005 and 2018.

This is a somewhat surprising result as previous studies (Ball et al., 2020; Dietmüller et al., 2021) suggest that models have larger trends in lower stratospheric ozone at mid latitude compared to observations from a merged stratospheric ozone dataset (Ball et al., 2018). However, trends in those studies were calculated from an earlier period (1998-2018) and for slightly different vertical columns, so there are a number of possible reasons why our results differ. The main question is why UKCA is underestimating Spring trends in lower stratospheric ozone compared to similarly sampled OMI data. Positive ozone trends in the upper stratosphere have been observed since 1998 (e.g. Harris et al., 2015; Steinbrecht et al., 2018;

610 Weber et al., 2018; Ball et al., 2018), which can be attributed to the reduction in ozone depleting substances driven by the Montreal protocol (WMO, 2018) and the cooling of the stratosphere due to increase in greenhouse gases and consequent decrease in the rate of ozone destruction (Portmann and Solomon, 2007). However, ozone in the mid latitude lower stratosphere (between 170-50 hPa) is more directly influenced by the lower branch of the Brewer Dobson circulation (Abalos et al., 2014; Dietmüller et al., 2018) and therefore more strongly linked to lower stratospheric ozone in the Tropics 615 (Dietmüller et al., 2021). Because of this, ozone in the mid latitude lower stratosphere is more likely to be affected by changes in the strength of tropical upwelling, which can be modulated by ENSO and the QBO (Neu et al., 2014), and driven by greenhouse gas increases and global warming (Butchart, 2014). 
https://doi.org/10.5194/acp-2022-99

Preprint. Discussion started: 2 March 2022

(C) Author(s) 2022. CC BY 4.0 License.

(c) (1)

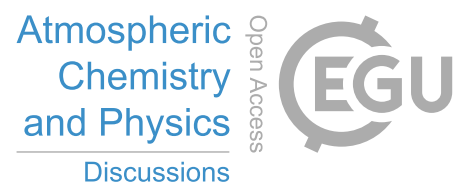

One possibility is that UKCA might overestimate the trend in tropical upwelling between 2005-2018, leading to an increased transport of ozone-poor air from the tropical troposphere to the mid-latitude lower stratosphere, and this could in turn result

620 in an underestimate in ozone trends in the mid latitude lower stratosphere. This grants further investigations that are however outside the scope of this study. 
a)
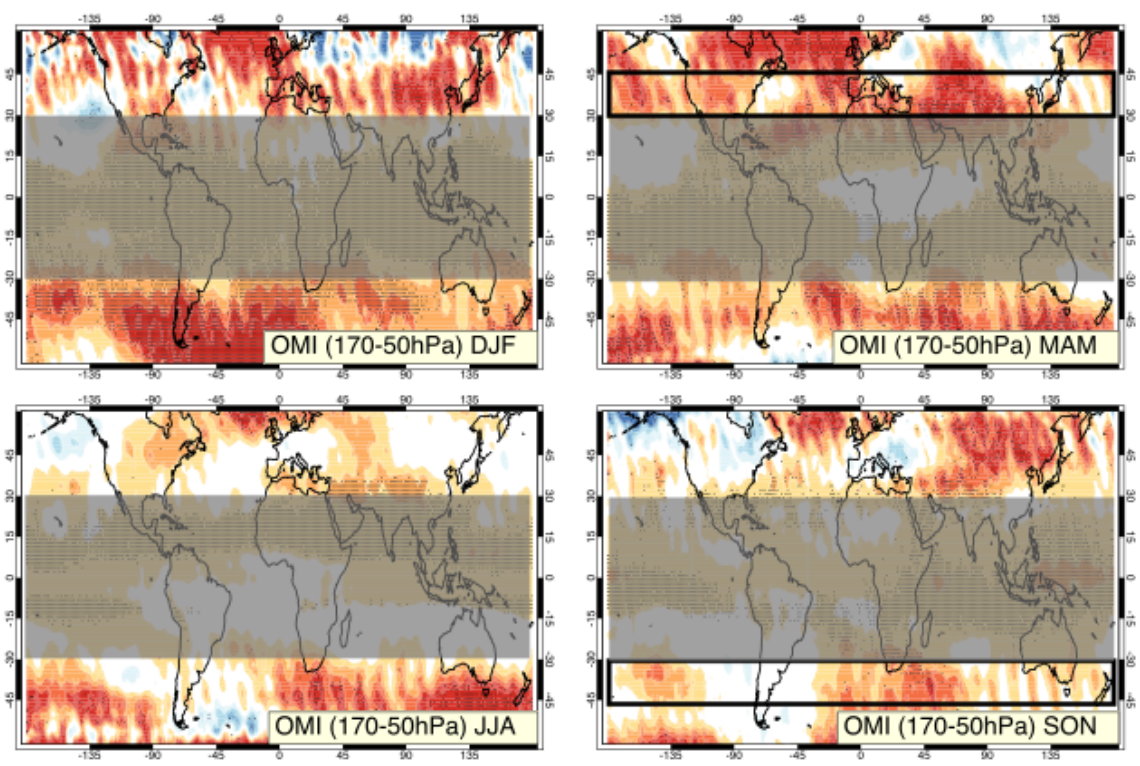

b)
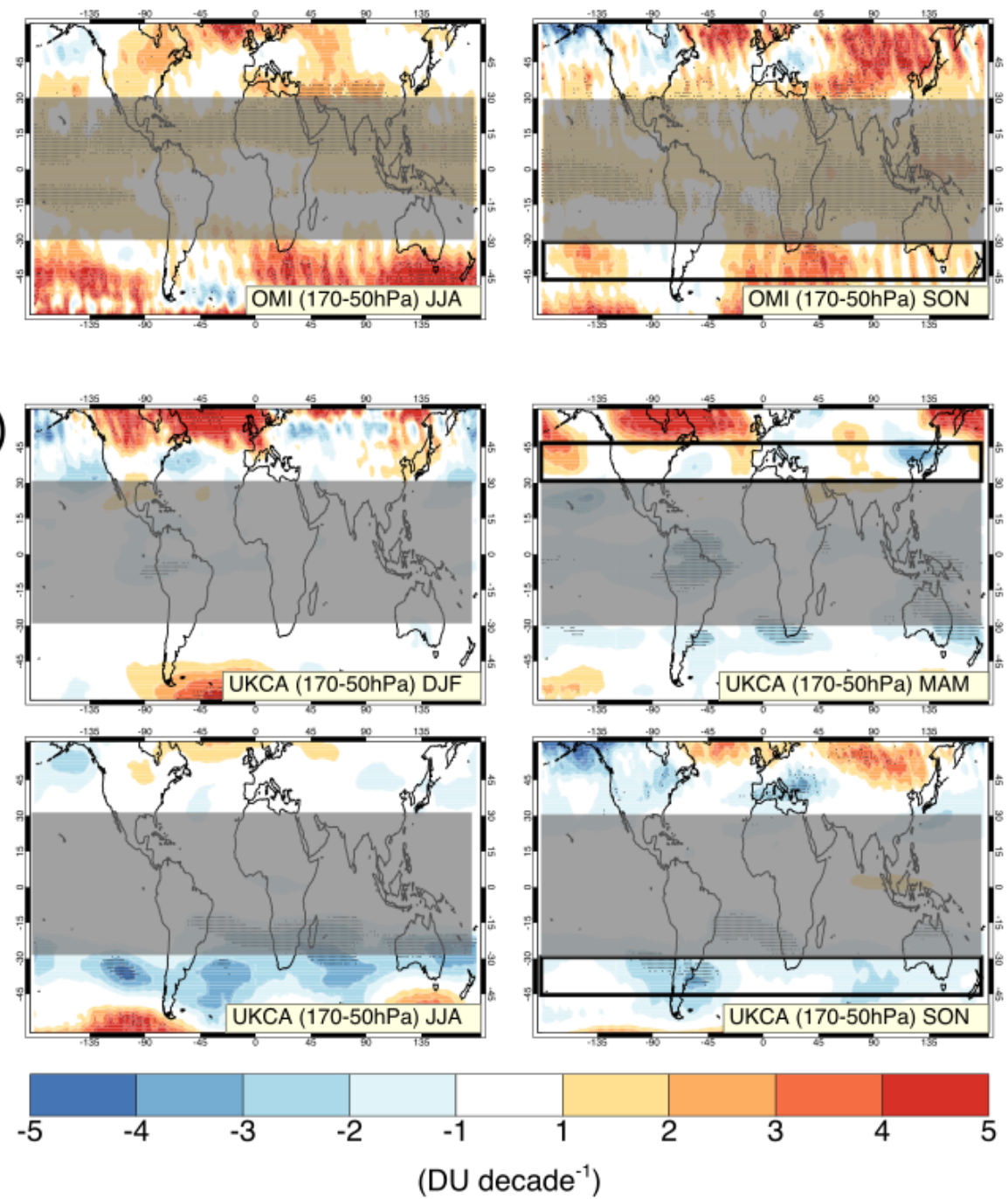

Figure 9: Seasonal trend maps of ozone columns sampled between 170-50hPa for OMI (a) and UKCA (b). The black boxes highlight regions and seasons most relevant for STT; shaded areas indicate regions where the vertical subcolumn samples the upper troposphere as well as the lower stratosphere. 


\subsection{Dynamical response of modelled STT and LiNOx emissions and their impact on North Atlantic ozone IAV}

In section 4.2 we have identified tropical NOx emissions and transport of ozone from the stratosphere as the two main drivers of modelled North Atlantic ozone IAV. In this section we investigate the impact of external dynamical forcing on the IAV of observed and modelled North Atlantic ozone and we further analyse possible reasons for the discrepancy between observed and modelled ozone IAV. Unlike anthropogenic emissions and other natural ozone precursor emissions (such as soil NOx and biomass burning), lightning NOx and ozone transported from the stratosphere are not imposed as model input but are diagnosed interactively within the model. Because of this, such sources of tropospheric ozone are therefore influenced by dynamical processes and climate modes of variability. ENSO affects convection and can therefore impact the strength and geographical distribution of lightning and LiNOx emissions (Chronis et al., 2008; Sátori et al., 2009), whilst the $\mathrm{AO}$ and NAO affect the strength and location of the storm track in the north Atlantic basin and can therefore impact downward transport from the stratosphere (Lamarque and Hess, 2004; Pausata et al., 2012, Reutter et al., ACP 2015).

640 In this study, we have analysed correlation maps between observed and modelled ozone and the AO/NAO indices for different vertical subcolumns and different seasons. The maps were derived by correlating monthly, detrended ozone timeseries for each gridpoint to the AO/NAO index. Very similar correlation patterns were found when using AO and NAO indices, and strongest correlation values were observed between ozone and the $\mathrm{AO}$ in the winter months (DJF); correlation maps between ozone and AO index in DJF are therefore shown. In Figure 10 observed ozone datasets (top row) show a consistent correlation pattern with the $\mathrm{AO}$ across all vertical subcolumns, i.e. negative correlation for latitudes between $30^{\circ}$ $\mathrm{N}: 50^{\circ} \mathrm{N}$ and positive correlation around $20^{\circ} \mathrm{N}$, although correlation values are decidedly smaller in the lower troposphere. Modelled ozone (middle row) shows a strikingly similar correlation pattern to OMI in the 450-170 hPa layer (Fig 10c and 10f), but there are significant differences in the way modelled TCO and LTCO respond to forcing by the AO, compared to observations. This suggests that the mechanism driving the ozone response to the $\mathrm{AO}$ is well captured by the model in the 450-170 hPa column but not in the lower troposphere, leading to differences in the full tropospheric column. 


\section{surf-tropopause}
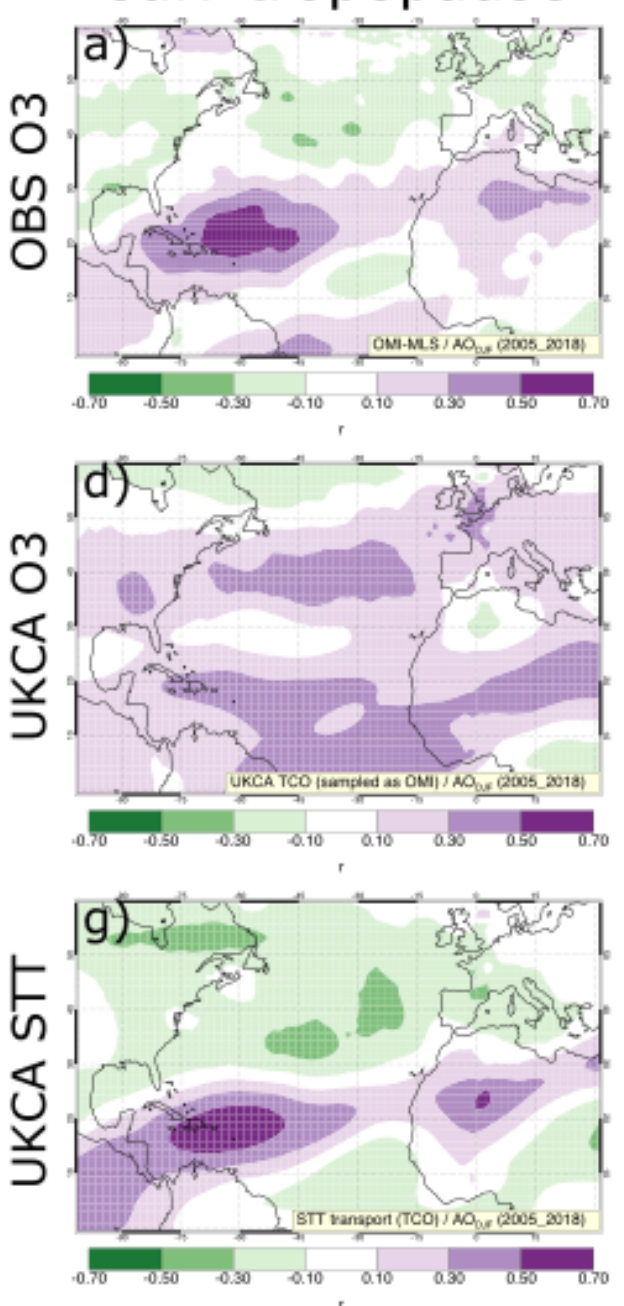

surf-6km
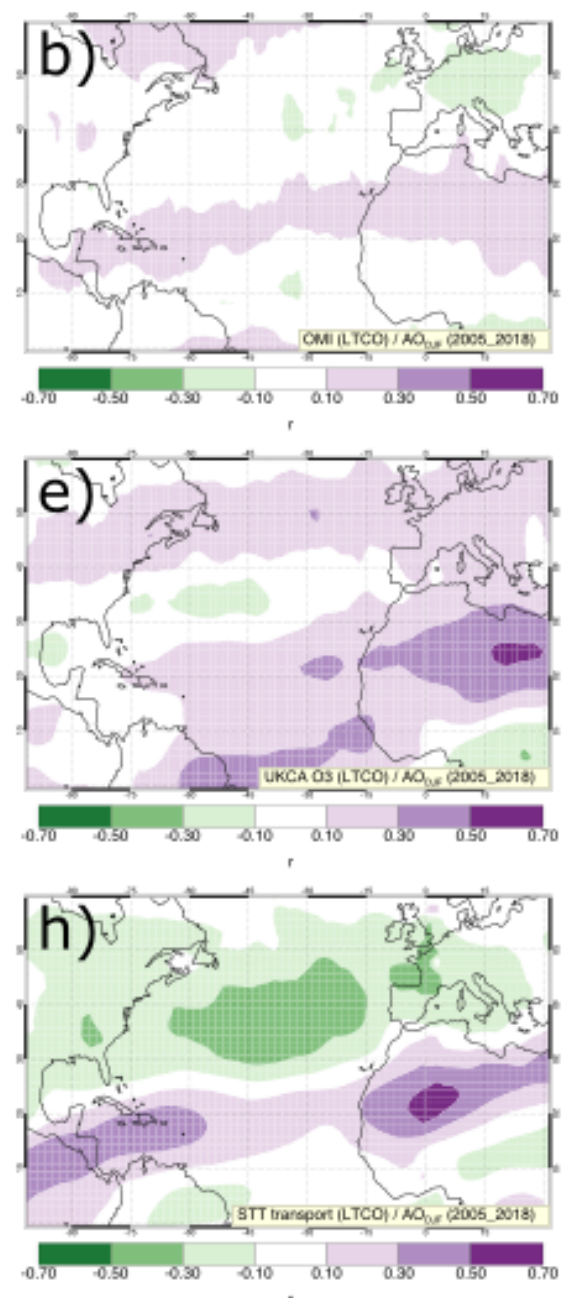

$\sim 6-13 \mathrm{~km}$
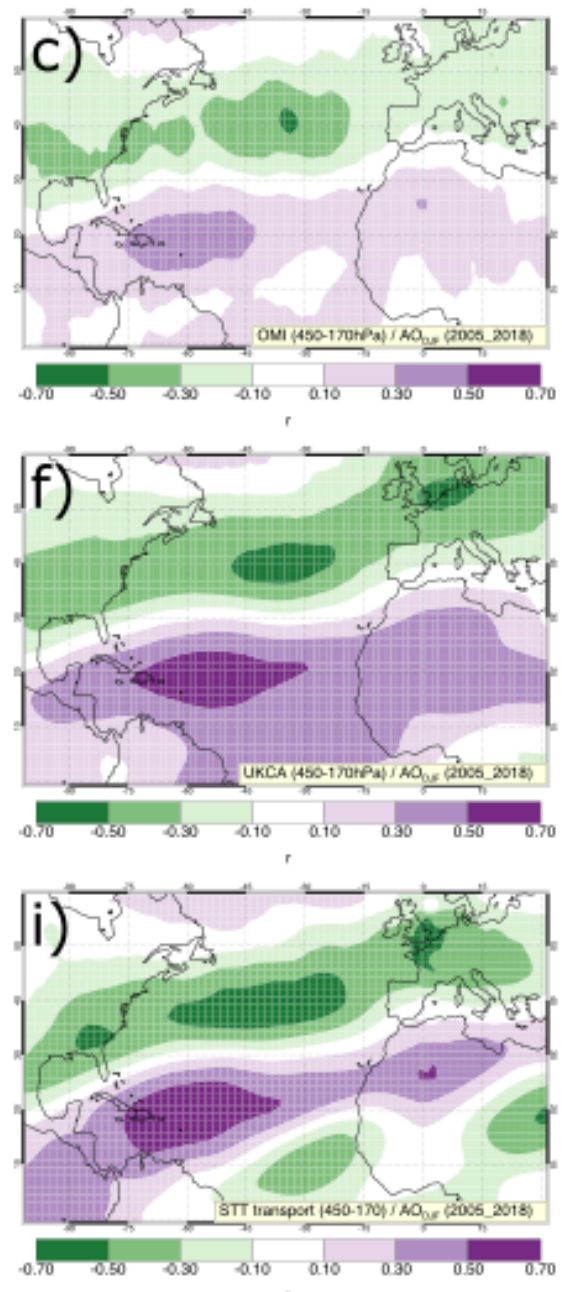

Figure 10: Correlation maps between the AO (in DJF) and observed ozone (top row), modelled ozone (middle row) and modelled stratosphere to troposphere transport (bottom row). The first column shows correlation for variables integrated over the full troposphere (surface to tropopause), while the second and third columns show correlation for variables integrated over the OMI subcolumns: surf-450 hPa ( $0-6 \mathrm{~km})$ and 450-170 hPa ( 6-13 km).

In order to investigate the role of STT on North Atlantic ozone response to the AO/NAO we used two modelled idealised tracers, O3S and O3S-C, which represent respectively 'ozone from STT' and its 'downward transport from the stratosphere'. The correlation maps between the AO and O3S-C are shown in the bottom row of Figure 10 and are very similar to correlation maps between the $\mathrm{AO}$ and $\mathrm{O} 3 \mathrm{~S}$ (not shown); regions where observed ozone is increased/decreased in response to 
the $\mathrm{AO}$ coincide with regions where modelled downward transport of ozone-rich stratospheric air is increased/decreased in response to the AO. The remarkably similar patterns between the observed ozone correlation maps and the modelled STT tracer correlation maps offer additional evidence that the impact of the AO on STT plays a large role in the tropospheric ozone response to the AO/NAO in winter, as previously inferred by Lamarque and Hess (2004) and Pausata et al. (2012).

665 Despite capturing the impact of the AO/NAO on STT, and therefore correctly replicating the ozone response in the 450-170 $\mathrm{hPa}$ region, modelled ozone in the troposphere and lower troposphere does not respond to the AO in the same way as observed ozone. This could be due to either long range transport of ozone from other regions not being correctly represented, or the fraction of ozone from STT reaching the lower troposphere being underestimated in the model.

ENSO is a leading mode of variability in the Tropics driven by anomalies in sea surface temperature across the Pacific ocean (Alexander et al., 2002). The geographical location of convection, and associated lightning NOx emissions, shifts with ENSO phases: positive ENSO favours convection over the Central Pacific and Africa, while negative ENSO favours convection over South America and the Maritime Continent. The impact of ENSO on tropospheric and stratospheric ozone has been previously investigated (Ziemke et al., 2010; Oman et al., 2013; Tweedy et al., 2018; Olsen et al., 2019). Here we focus on the response of modelled North Atlantic ozone to ENSO and discrepancies between modelled and observed ozone response to ENSO. Figure 11 shows deseasonalised and detrended timeseries anomalies of (a) observed and modelled ozone in the North Atlantic and (b) tropical lightning flashes. Correlation coefficients between these timeseries and the ENSO3.4 index are reported in the legends; note that the lightning flash timeseries is plotted for a different period (1996-2013) due to the availability of lightning flash observations. Also note that both panels in Fig 11 show timeseries of the negative ENSO index (-ENSO). From Figure 11a it is clear that, whilst observed ozone datasets have no significant correlation to ENSO, modelled ozone is fairly strongly correlated to -ENSO, with the lower tropospheric column being somewhat less influenced by ENSO compared to the full tropospheric column. The reason for the different response of observed and modelled North Atlantic ozone to ENSO can be explained by Figure 11b: observed lightning flashes in the Tropics are not significantly correlated to -ENSO, but modelled lightning flashes are correlated to -ENSO. The increased tropical lightning in the model, associated to negative ENSO events, leads to increased LiNOx emissions in the Tropics which drives an increase in modelled North Atlantic ozone. Analysis of the geographical distribution of lightning flashes suggests that the reason for the discrepancy between observed and modelled lightning flashes response to ENSO arises from the convection and lightning parameterisations. Oceanic convection is underestimated in the model, leading to an underestimate of LiNOx emissions and ozone production in the Tropics during positive ENSO events. 
a)

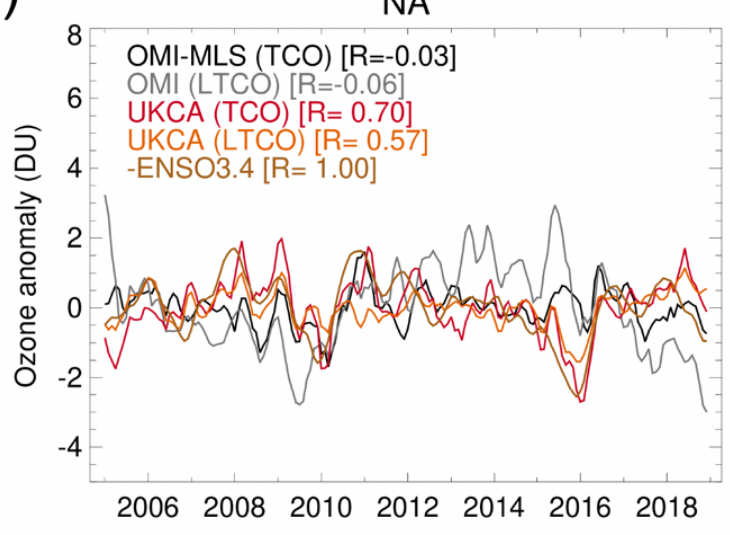

b)

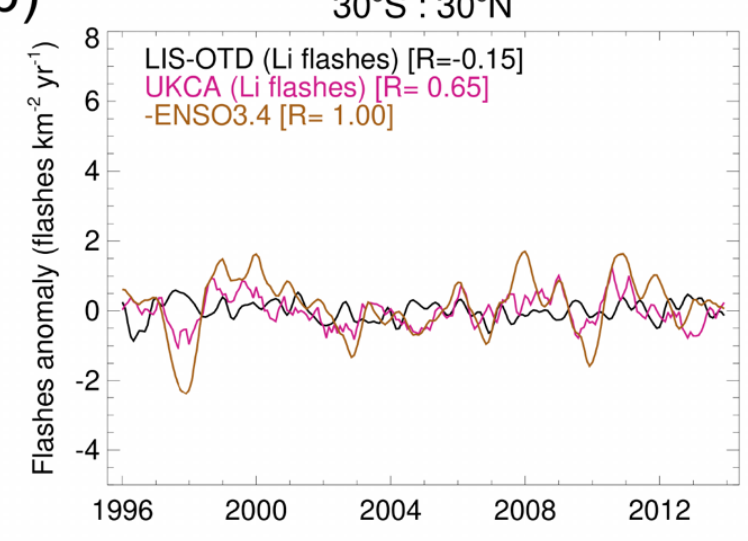

Figure 11: Deseasonalised and detrended timeseries anomalies of (a) observed and modelled ozone in the North Atlantic and (b) tropical lightning flashes. The -ENSO index timeseries is also plotted for comparison. Correlation coefficients $(R)$ between each timeseries and the -ENSO index are noted in the legends.

Since modelled tropospheric ozone in the North Atlantic responds differently to AO and ENSO compared to observed ozone, the interannual variability of modelled tropospheric ozone does not match the observed ozone interannual variability. In contrast, temporal correlation between observed and modelled stratospheric ozone (measured between 170-50hPa) are fairly high, with correlation coefficients as high as 0.75 for mid latitude North Atlantic; this does not occur for model simulations where nudging is not applied, suggesting that stratospheric ozone interannual variability is driven by dynamical processes whose temporal evolution is correctly captured in a nudged model integration.

\section{Conclusions}

This work aimed to investigate the seasonal, interannual and decadal variability of tropospheric ozone in satellite data and 3D CCM output from the UM-UKCA model, and to understand what factors are driving such changes, with a specific focus on the North Atlantic region.

The model does a good overall job of capturing the ozone burden and spatial distribution of ozone in the North Atlantic. The seasonal cycle of ozone in the North Atlantic is well captured by the UKCA model. Both model and observations show a broad maximum in spring and early summer which is consistent with the two major sources of tropospheric ozone: transport from the stratosphere (with a maximum in late spring and early summer) and photochemical production from ozone precursors' emissions (with a maximum in summer). However, analysis of observed and modelled deseasonalised ozone 
timeseries for the period 2005-2018 shows that the interannual variability of ozone is different in the model compared to the observations. Whilst modelled LTCO has a smaller interannual variability compared to OMI, modelled TCO seems to have a larger interannual variability in the Tropical North Atlantic. In order to understand the drivers of modelled ozone interannual variability in the North Atlantic we calculated correlation coefficients for the deseasonalised and detrended timeseries anomalies of ozone and a number of possible ozone drivers. The interannual variability of UKCA ozone in the North Atlantic is very strongly correlated to interannual variability of ozone transported from the stratosphere (quantified using a modelled idealised tracer) and tropical lightning NOx emissions. The interannual variability of ozone transported from the stratosphere and tropical lightning NOx emissions are in turn influenced by large scale modes of variability such as $\mathrm{AO} / \mathrm{NAO}$ and ENSO, but the modelled response to such modes of variability is different from the observed response. In particular, tropical lightning and ozone are too strongly correlated to ENSO compared to observations. Using OMI data retrieved in discrete vertical layers, in addition to model idealised tracers, we find that the dynamical response of STT to the $\mathrm{AO}$ can explain the observed tropospheric ozone response to the $\mathrm{AO} / \mathrm{NAO}$ in winter.

Using OMI height-resolved data, in addition to OMI-MLS TCO, we can confirm that UKCA positive ozone bias in the Tropics is the result of a large bias in the tropical upper troposphere and a much smaller bias in the tropical lower troposphere. The model tropical bias is larger than the difference in TCO values associated with a different choice of tropopause, and it is therefore not an artifact of tropospheric column definition.

730 Further analysis, including sensitivity experiments and comparison with an observed lightning flash climatology from LISOTD, shows that the positive bias in the tropical upper troposphere is due to shortfalls in the convection and lightning flash parameterisations in the model, leading to an overestimate of lightning NOx emissions and consequent overestimate of ozone formation in the Tropics. Efforts are currently underway to improve the lightning parameterisation in the model.

735 The model negative bias at southern mid- and high latitudes and northern high latitudes, relative to OMI-MLS TCO, is not supported by comparison with OMI data: analysis of UKCA and OMI ozone in the lower troposphere, with and without the use of satellite operator, suggests that the negative bias at such latitudes relative to OMI-MLS could be the result of incorrect model sampling due to the fact that averaging kernels are not available for the OMI-MLS dataset. This is further supported by generally good agreement between modelled and Bodecker Scientific ozone vertical profiles at mid latitudes.

Both satellite datasets show a positive linear trend in ozone of $\sim 1.6-1.7 \mathrm{DU}$ decade ${ }^{-1}$ for the tropical North Atlantic but observed trends differ for mid-latitude North Atlantic. UKCA has a tendency to underestimate ozone trends both in the North Atlantic and globally. Our analysis points to differences between observed and modelled lower stratospheric ozone trends in spring as a possible source for the model's underestimate of tropospheric ozone trends. Estimating trends from both satellites and models is still a challenge since decadal changes are small compared to seasonal and interannual variability. 
https://doi.org/10.5194/acp-2022-99

(c) Author(s) 2022 CC BY 4.0 License.

However, improvements to the quality of data from satellite uv sounders, which extend back to 1995, and continued monitoring from current and planned satellites should enable shorter and longer-term variability to be better discriminated. We encourage further studies that incorporate pairs of ozone tracers (e.g., O3S and O3S-C), as we have done in this work, to better constrain the processes controlling the effects of stratospheric ozone trends on tropospheric ozone.

\section{Acknowledgements}

MRR, NLA, BGL, RS and ATA would like to thank NERC for financial support through the "North Atlantic Climate System Integrated Study" (ACSIS) project. The RAL scheme to retrieve ozone height-resolved profiles (L2 data) from 755 satellite UV sounders was developed through NERC's NCEO (award NE/R016518/1) and ESA's Climate Change Initiative. Production and analysis of gridded OMI (L3) data by RAL was funded through NCEO. ATA, NLA and JMK thank the Met Office CSSP-China programme for funding the POzSUM project. Model integrations were performed on MONSooN2 (a collaborative High-Performance Computing facility funded by the Met Office and the Natural Environment Research Council) and NEXCS (a High-Performance Computing facility funded by the Natural Environment Research Council and

760 delivered by the Met Office between 2017 and 2021). This work used JASMIN, the UK collaborative data analysis facility. ATA thanks NERC PROMOTE project for funding (NE/P016383/1). 


\section{References}

Abalos, M., Orbe, C., Kinnison, D. E., Plummer, D., Oman, L. D., Jöckel, P., Morgenstern, O., Garcia, R. R., Zeng, G., Stone, K. A. and Dameris, M.: Future trends in stratosphere-to-troposphere transport in CCMI models, Atmospheric Chemistry and Physics, 20(11), 6883-6901, doi:10.5194/acp-20-6883-2020, 2020.

Abalos, M., Randel, W. J. and Serrano, E.: Dynamical Forcing of Subseasonal Variability in the Tropical Brewer-Dobson Circulation, Journal of the Atmospheric Sciences, 71(9), 3439-3453, doi:10.1175/jas-d-13-0366.1, 2014.

Achakulwisut, P., Mickley, L. J., Murray, L. T., Tai, A. P. K., Kaplan, J. O. and Alexander, B.: Uncertainties in isoprene photochemistry and emissions: implications for the oxidative capacity of past and present atmospheres and for climate forcing agents, Atmospheric Chemistry and Physics, 15(14), 7977-7998, doi:10.5194/acp-15-7977-2015, 2015.

Aghedo, A. M., Bowman, K. W., Shindell, D. T. and Faluvegi, G.: The impact of orbital sampling, monthly averaging and vertical resolution on climate chemistry model evaluation with satellite observations, Atmospheric Chemistry and Physics, 11(13), 6493-6514, doi:10.5194/acp-11-6493-2011, 2011.

Alexander, M. A., Bladé, I., Newman, M., Lanzante, J. R., Lau, N.-C. and Scott, J. D.: The Atmospheric Bridge: The Influence of ENSO Teleconnections on Air-Sea Interaction over the Global Oceans, Journal of Climate, 15(16), 2205-2231, doi:10.1175/1520-0442(2002)015<2205:TABTIO>2.0.CO;2, 2002

780 Archer-Nicholls, S., Abraham, N. L., Shin, Y. M., Weber, J., Russo, M. R., Lowe, D., Utembe, S. R., O’Connor, F. M., Kerridge, B., Latter, B., Siddans, R., Jenkin, M., Wild, O. and Archibald, A. T.: The Common Representative Intermediates Mechanism Version 2 in the United Kingdom Chemistry and Aerosols Model, Journal of Advances in Modeling Earth Systems, 13(5), doi:10.1029/2020ms002420, 2021.

Archibald, A. T., Neu, J. L., Elshorbany, Y. F., Cooper, O. R., Young, P. J., Akiyoshi, H., Cox, R. A., Coyle, M., Derwent, R. G., Deushi, M., Finco, A., Frost, G. J., Galbally, I. E., Gerosa, G., Granier, C., Griffiths, P. T., Hossaini, R., Hu, L., Jöckel, P., Josse, B., Lin, M. Y., Mertens, M., Morgenstern, O., Naja, M., Naik, V., Oltmans, S., Plummer, D. A., Revell, L. E., Saiz-Lopez, A., Saxena, P., Shin, Y. M., Shahid, I., Shallcross, D., Tilmes, S., Trickl, T., Wallington, T. J., Wang, T., Worden, H. M. and Zeng, G.: Tropospheric Ozone Assessment Report, Elementa: Science of the Anthropocene, 8(1), doi:10.1525/elementa.2020.034, 2020a.

790 Archibald, A. T., O’Connor, F. M., Abraham, N. L., Archer-Nicholls, S., Chipperfield, M. P., Dalvi, M., Folberth, G. A., Dennison, F., Dhomse, S. S., Griffiths, P. T., Hardacre, C., Hewitt, A. J., Hill, R. S., Johnson, C. E., Keeble, J., Köhler, M. O., Morgenstern, O., Mulcahy, J. P., Ordóñez, C., Pope, R. J., Rumbold, S. T., Russo, M. R., Savage, N. H., Sellar, A., Stringer, M., Turnock, S. T., Wild, O. and Zeng, G.: Description and evaluation of the UKCA stratosphere-troposphere chemistry scheme (StratTrop vn 1.0) implemented in UKESM1, Geoscientific Model Development, 13(3), 1223-1266, 795 doi:10.5194/gmd-13-1223-2020, 2020b.

Arneth, A., Niinemets, Ü., Pressley, S., Bäck, J., Hari, P., Karl, T., Noe, S., Prentice, I. C., Serça, D., Hickler, T., Wolf, A. and Smith, B.: Process-based estimates of terrestrial ecosystem isoprene emissions: incorporating the effects of a direct CO2isoprene interaction, Atmospheric Chemistry and Physics, 7(1), 31-53, doi:10.5194/acp-7-31-2007, 2007.

Ball, W. T., Chiodo, G., Abalos, M., Alsing, J. and Stenke, A.: Inconsistencies between chemistry-climate models and observed lower stratospheric ozone trends since 1998, Atmospheric Chemistry and Physics, 20(16), 9737-9752, doi:10.5194/acp-20-9737-2020, 2020.

Boccippio, D. J., Koshak, W. J. and Blakeslee, R. J.: Performance Assessment of the Optical Transient Detector and Lightning Imaging Sensor. Part I: Predicted Diurnal Variability, Journal of Atmospheric and Oceanic Technology, 19(9), 1318-1332, doi:10.1175/1520-0426(2002)019<1318:paotot>2.0.co;2, 2002.

805 Butchart, N.: The Brewer-Dobson circulation, Reviews of Geophysics, 52(2), 157-184, doi:10.1002/2013rg000448, 2014.

Butler, T., Lupascu, A., Coates, J. and Zhu, S.: TOAST 1.0: Tropospheric Ozone Attribution of Sources with Tagging for CESM 1.2.2, Geoscientific Model Development, 11(7), 2825-2840, doi:10.5194/gmd-11-2825-2018, 2018. 
https://doi.org/10.5194/acp-2022-99

Preprint. Discussion started: 2 March 2022

(c) Author(s) 2022. CC BY 4.0 License.

Atmospheric

Chemistry

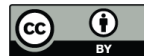

and Physics

Discussions

Cecil, D. and NASA MSFC: LIS/OTD 2.5 Degree Low Resolution Monthly Time Series (LRMTS), doi:10.5067/LIS/LISOTD/DATA309, 2006.

810 Cecil, D. J., Buechler, D. E. and Blakeslee, R. J.: Gridded lightning climatology from TRMM-LIS and OTD: Dataset description, Atmospheric Research, 135-136, 404-414, doi:10.1016/j.atmosres.2012.06.028, 2014.

Christian, H. J.: Global frequency and distribution of lightning as observed from space by the Optical Transient Detector, Journal of Geophysical Research, 108(D1), doi:10.1029/2002jd002347, 2003.

Chronis, T. G., Goodman, S. J., Cecil, D., Buechler, D., Robertson, F. J., Pittman, J. and Blakeslee, R. J.: Global lightning

activity from the ENSO perspective, Geophysical Research Letters, 35(19), doi:10.1029/2008g1034321, 2008.

Cooper, O. R., Parrish, D. D., Ziemke, J., Balashov, N. V., Cupeiro, M., Galbally, I. E., Gilge, S., Horowitz, L., Jensen, N. R., Lamarque, J.-F., Naik, V., Oltmans, S. J., Schwab, J., Shindell, D. T., Thompson, A. M., Thouret, V., Wang, Y. and Zbinden, R. M.: Global distribution and trends of tropospheric ozone: An observation-based review, edited by D. Helmig and P. Palmer, Elementa: Science of the Anthropocene, 2, doi:10.12952/journal.elementa.000029, 2014.

820 Cooper, O. R., Schultz, M. G., Schröder, S., Chang, K.-L., Gaudel, A., Benítez, G. C., Cuevas, E., Fröhlich, M., Galbally, I. E., Molloy, S., Kubistin, D., Lu, X., McClure-Begley, A., Nédélec, P., O’Brien, J., Oltmans, S. J., Petropavlovskikh, I., Ries, L., Senik, I., Sjöberg, K., Solberg, S., Spain, G. T., Spangl, W., Steinbacher, M., Tarasick, D., Thouret, V. and Xu, X.: Multi-decadal surface ozone trends at globally distributed remote locations, edited by D. Helmig and I. Faloona, Elementa: Science of the Anthropocene, 8, doi:10.1525/elementa.420, 2020.

825 Creilson, J. K., Fishman, J. and Wozniak, A. E.: Intercontinental transport of tropospheric ozone: a study of its seasonal variability across the North Atlantic utilizing tropospheric ozone residuals and its relationship to the North Atlantic Oscillation, Atmospheric Chemistry and Physics, 3(6), 2053-2066, doi:10.5194/acp-3-2053-2003, 2003.

Creilson, J. K., Fishman, J. and Wozniak, A. E.: Arctic Oscillation-induced variability in satellite-derived tropospheric ozone, Geophysical Research Letters, 32(14), n/a-n/a, doi:10.1029/2005gl023016, 2005.

830 Dee, D. P., Uppala, S. M., Simmons, A. J., Berrisford, P., Poli, P., Kobayashi, S., Andrae, U., Balmaseda, M. A., Balsamo, G., Bauer, P., Bechtold, P., Beljaars, A. C. M., van de Berg, L., Bidlot, J., Bormann, N., Delsol, C., Dragani, R., Fuentes, M., Geer, A. J., Haimberger, L., Healy, S. B., Hersbach, H., Hólm, E. V., Isaksen, L., Kållberg, P., Köhler, M., Matricardi, M., McNally, A. P., Monge-Sanz, B. M., Morcrette, J.-J., Park, B.-K., Peubey, C., de Rosnay, P., Tavolato, C., Thépaut, J.-N. and Vitart, F.: The ERA-Interim reanalysis: configuration and performance of the data assimilation system, Quarterly Journal of the Royal Meteorological Society, 137(656), 553-597, doi:10.1002/qj.828, 2011.

Dietmüller, S., Eichinger, R., Garny, H., Birner, T., Boenisch, H., Pitari, G., Mancini, E., Visioni, D., Stenke, A., Revell, L., Rozanov, E., Plummer, D. A., Scinocca, J., Jöckel, P., Oman, L., Deushi, M., Kiyotaka, S., Kinnison, D. E., Garcia, R., Morgenstern, O., Zeng, G., Stone, K. A. and Schofield, R.: Quantifying the effect of mixing on the mean age of air in CCMVal-2 and CCMI-1 models, Atmospheric Chemistry and Physics, 18(9), 6699-6720, doi:10.5194/acp-18-6699-2018, 8402018.

Dietmüller, S., Garny, H., Eichinger, R. and Ball, W. T.: Analysis of recent lower-stratospheric ozone trends in chemistry climate models, Atmospheric Chemistry and Physics, 21(9), 6811-6837, doi:10.5194/acp-21-6811-2021, 2021.

Ebojie, F., Burrows, J. P., Gebhardt, C., Ladstätter-Weißenmayer, A., von Savigny, C., Rozanov, A., Weber, M. and Bovensmann, H.: Global tropospheric ozone variations from 2003 to 2011 as seen by SCIAMACHY, Atmospheric

845 Chemistry and Physics, 16(2), 417-436, doi:10.5194/acp-16-417-2016, 2016.

Feng, L., Smith, S. J., Braun, C., Crippa, M., Gidden, M. J., Hoesly, R., Klimont, Z., van Marle, M., van den Berg, M. and van der Werf, G. R.: The generation of gridded emissions data for CMIP6, Geoscientific Model Development, 13(2), 461482, doi:10.5194/gmd-13-461-2020, 2020.

Finney, D. L., Doherty, R. M., Wild, O., Huntrieser, H., Pumphrey, H. C. and Blyth, A. M.: Using cloud ice flux to 850 parametrise large-scale lightning, Atmospheric Chemistry and Physics, 14(23), 12665-12682, doi:10.5194/acp-14-126652014, 2014. 
Gaudel, A., Cooper, O. R., Ancellet, G., Barret, B., Boynard, A., Burrows, J. P., Clerbaux, C., Coheur, P.-F., Cuesta, J., Cuevas, E., Doniki, S., Dufour, G., Ebojie, F., Foret, G., Garcia, O., Granados-Muñoz, M. J., Hannigan, J. W., Hase, F., Hassler, B., Huang, G., Hurtmans, D., Jaffe, D., Jones, N., Kalabokas, P., Kerridge, B., Kulawik, S., Latter, B., Leblanc, T., Le Flochmoën, E., Lin, W., Liu, J., Liu, X., Mahieu, E., McClure-Begley, A., Neu, J. L., Osman, M., Palm, M., Petetin, H., Petropavlovskikh, I., Querel, R., Rahpoe, N., Rozanov, A., Schultz, M. G., Schwab, J., Siddans, R., Smale, D., Steinbacher, M., Tanimoto, H., Tarasick, D. W., Thouret, V., Thompson, A. M., Trickl, T., Weatherhead, E., Wespes, C., Worden, H. M., Vigouroux, C., Xu, X., Zeng, G. and Ziemke, J.: Tropospheric Ozone Assessment Report: Present-day distribution and trends of tropospheric ozone relevant to climate and global atmospheric chemistry model evaluation, edited by D. Helmig and A. Lewis, Elementa: Science of the Anthropocene, 6, doi:10.1525/elementa.291, 2018.

Grewe, V.: Impact of climate variability on tropospheric ozone, Science of The Total Environment, 374(1), 167-181, doi:10.1016/j.scitotenv.2007.01.032, 2007.

Griffiths, P. T., Keeble, J., Shin, Y. M., Abraham, N. L., Archibald, A. T. and Pyle, J. A.: On the Changing Role of the Stratosphere on the Tropospheric Ozone Budget: 1979-2010, Geophysical Research Letters, 47(10), doi:10.1029/2019g1086901, 2020.

Griffiths, P. T., Murray, L. T., Zeng, G., Shin, Y. M., Abraham, N. L., Archibald, A. T., Deushi, M., Emmons, L. K., Galbally, I. E., Hassler, B., Horowitz, L. W., Keeble, J., Liu, J., Moeini, O., Naik, V., O’Connor, F. M., Oshima, N., Tarasick, D., Tilmes, S., Turnock, S. T., Wild, O., Young, P. J. and Zanis, P.: Tropospheric ozone in CMIP6 simulations, Atmospheric Chemistry and Physics, 21(5), 4187-4218, doi:10.5194/acp-21-4187-2021, 2021.

870 Harris, N. R. P., Hassler, B., Tummon, F., Bodeker, G. E., Hubert, D., Petropavlovskikh, I., Steinbrecht, W., Anderson, J., Bhartia, P. K., Boone, C. D., Bourassa, A., Davis, S. M., Degenstein, D., Delcloo, A., Frith, S. M., Froidevaux, L., GodinBeekmann, S., Jones, N., Kurylo, M. J., Kyrölä, E., Laine, M., Leblanc, S. T., Lambert, J.-C., Liley, B., Mahieu, E., Maycock, A., de Mazière, M., Parrish, A., Querel, R., Rosenlof, K. H., Roth, C., Sioris, C., Staehelin, J., Stolarski, R. S., Stübi, R., Tamminen, J., Vigouroux, C., Walker, K. A., Wang, H. J., Wild, J. and Zawodny, J. M.: Past changes in the

875 vertical distribution of ozone - Part 3: Analysis and interpretation of trends, Atmospheric Chemistry and Physics, 15(17), 9965-9982, doi:10.5194/acp-15-9965-2015, 2015.

Hassler, B., Kremser, S., Bodeker, G. E., Lewis, J., Nesbit, K., Davis, S. M., Chipperfield, M. P., Dhomse, S. S. and Dameris, M.: An updated version of a gap-free monthly mean zonal mean ozone database, Earth System Science Data, 10(3), 1473-1490, doi:10.5194/essd-10-1473-2018, 2018.

880 Hess, P. G. and Lamarque, J.-F.: Ozone source attribution and its modulation by the Arctic oscillation during the spring months, Journal of Geophysical Research, 112(D11), doi:10.1029/2006jd007557, 2007.

Hess, P. G. and Zbinden, R.: Stratospheric impact on tropospheric ozone variability and trends: 1990-2009, Atmospheric Chemistry and Physics, 13(2), 649-674, doi:10.5194/acp-13-649-2013, 2013.

Heue, K.-P., Coldewey-Egbers, M., Delcloo, A., Lerot, C., Loyola, D., Valks, P. and van Roozendael, M.: Trends of tropical

885 tropospheric ozone from 20 years of European satellite measurements and perspectives for the Sentinel-5 Precursor, Atmospheric Measurement Techniques, 9(10), 5037-5051, doi:10.5194/amt-9-5037-2016, 2016.

Hollaway, M. J., Arnold, S. R., Collins, W. J., Folberth, G. and Rap, A.: Sensitivity of midnineteenth century tropospheric ozone to atmospheric chemistry-vegetation interactions, Journal of Geophysical Research: Atmospheres, 122(4), 2452-2473, doi:10.1002/2016jd025462, 2017.

890 Horowitz, L. W., Naik, V., Paulot, F., Ginoux, P. A., Dunne, J. P., Mao, J., Schnell, J., Chen, X., He, J., John, J. G., Lin, M., Lin, P., Malyshev, S., Paynter, D., Shevliakova, E. and Zhao, M.: The GFDL Global Atmospheric Chemistry-Climate Model AM4.1: Model Description and Simulation Characteristics, Journal of Advances in Modeling Earth Systems, 12(10), doi:10.1029/2019ms002032, 2020.

Hurrell, J. W.: Decadal Trends in the North Atlantic Oscillation: Regional Temperatures and Precipitation, Science, 
Kaplan, J. O. and Lau, K. H.-K.: The WGLC global gridded lightning climatology and time series, Earth System Science Data, 13(7), 3219-3237, doi:10.5194/essd-13-3219-2021, 2021.

Kaplan, J. O. and Lau, K. H.-K.: The WGLC global gridded lightning climatology and time series, Earth System Science Data, 13(7), 3219-3237, doi:10.5194/essd-13-3219-2021, 2021.

900 Karset, I. H. H., Berntsen, T. K., Storelvmo, T., Alterskjær, K., Grini, A., Olivié, D., Kirkevåg, A., Seland, Ø., Iversen, T. and Schulz, M.: Strong impacts on aerosol indirect effects from historical oxidant changes, Atmospheric Chemistry and Physics, 18(10), 7669-7690, doi:10.5194/acp-18-7669-2018, 2018.

Lamarque, J.-F. and Hess, P. G.: Arctic Oscillation modulation of the Northern Hemisphere spring tropospheric ozone, Geophysical Research Letters, 31(6), n/a-n/a, doi:10.1029/2003g1019116, 2004.

905 Lamarque, J.-F., Bond, T. C., Eyring, V., Granier, C., Heil, A., Klimont, Z., Lee, D., Liousse, C., Mieville, A., Owen, B., Schultz, M. G., Shindell, D., Smith, S. J., Stehfest, E., Van Aardenne, J., Cooper, O. R., Kainuma, M., Mahowald, N., McConnell, J. R., Naik, V., Riahi, K. and van Vuuren, D. P.: Historical (1850-2000) gridded anthropogenic and biomass burning emissions of reactive gases and aerosols: methodology and application, Atmospheric Chemistry and Physics, 10(15), 7017-7039, doi:10.5194/acp-10-7017-2010, 2010.

910 Lamarque, J.-F., Hess, P. G. and Tie, X. X.: Three-dimensional model study of the influence of stratosphere-troposphere exchange and its distribution on tropospheric chemistry, Journal of Geophysical Research: Atmospheres, 104(D21), 2636326372, doi:10.1029/1999jd900762, 1999.

Lelieveld, J. and Dentener, F. J.: What controls tropospheric ozone?, Journal of Geophysical Research: Atmospheres, 105(D3), 3531-3551, doi:10.1029/1999jd901011, 2000.

915 Levelt, P. F., van den Oord, G. H. J., Dobber, M. R., Malkki, A., Huib Visser, Johan de Vries, Stammes, P., Lundell, J. O. V. and Saari, H.: The ozone monitoring instrument, IEEE Transactions on Geoscience and Remote Sensing, 44(5), 1093-1101, doi:10.1109/tgrs.2006.872333, 2006.

Liaskos, C. E., Allen, D. J. and Pickering, K. E.: Sensitivity of tropical tropospheric composition to lightning NOx production as determined by replay simulations with GEOS-5, Journal of Geophysical Research: Atmospheres, 120(16), 8512-8534, doi:10.1002/2014jd022987, 2015.

Liu, J., Rodriguez, J. M., Oman, L. D., Douglass, A. R., Olsen, M. A. and Hu, L.: Stratospheric impact on the Northern Hemisphere winter and spring ozone interannual variability in the troposphere, Atmospheric Chemistry and Physics, 20(11), 6417-6433, doi:10.5194/acp-20-6417-2020, 2020.

Luhar, A. K., Galbally, I. E., Woodhouse, M. T. and Abraham, N. L.: Assessing and improving cloud-height-based

925 parameterisations of global lightning flash rate, and their impact on lightning-produced NO\&lt;sub\&gt;\&lt;i\&gt;x\&lt;/i\&gt;\&lt;/sub\&gt; and tropospheric composition in a chemistry-climate model, Atmospheric Chemistry and Physics, 21(9), 7053-7082, doi:10.5194/acp-21-7053-2021, 2021.

Martin, R. V., Sauvage, B., Folkins, I., Sioris, C. E., Boone, C., Bernath, P. and Ziemke, J.: Space-based constraints on the production of nitric oxide by lightning, Journal of Geophysical Research, 112(D9), doi:10.1029/2006jd007831, 2007.

930 Miles, G. M., Siddans, R., Kerridge, B. J., Latter, B. G. and Richards, N. A. D.: Tropospheric ozone and ozone profiles retrieved from GOME-2 and their validation, Atmospheric Measurement Techniques, 8(1), 385-398, doi:10.5194/amt-8385-2015, 2015.

Monks, P. S., Archibald, A. T., Colette, A., Cooper, O., Coyle, M., Derwent, R., Fowler, D., Granier, C., Law, K. S., Mills, G. E., Stevenson, D. S., Tarasova, O., Thouret, V., von Schneidemesser, E., Sommariva, R., Wild, O. and Williams, M. L.:

935 Tropospheric ozone and its precursors from the urban to the global scale from air quality to short-lived climate forcer, Atmospheric Chemistry and Physics, 15(15), 8889-8973, doi:10.5194/acp-15-8889-2015, 2015. 
Morgenstern, O., Braesicke, P., O’Connor, F. M., Bushell, A. C., Johnson, C. E., Osprey, S. M. and Pyle, J. A.: Evaluation of the new UKCA climate-composition model - Part 1: The stratosphere, Geoscientific Model Development, 2(1), 43-57, doi:10.5194/gmd-2-43-2009, 2009.

940 Nault, B. A., Laughner, J. L., Wooldridge, P. J., Crounse, J. D., Dibb, J., Diskin, G., Peischl, J., Podolske, J. R., Pollack, I. B., Ryerson, T. B., Scheuer, E., Wennberg, P. O. and Cohen, R. C.: Lightning NOx Emissions: Reconciling Measured and Modeled Estimates With Updated NOx Chemistry, Geophysical Research Letters, 44(18), 9479-9488, doi:10.1002/2017g1074436, 2017.

Neu, J. L., Flury, T., Manney, G. L., Santee, M. L., Livesey, N. J. and Worden, J.: Tropospheric ozone variations governed by changes in stratospheric circulation, Nature Geoscience, 7(5), 340-344, doi:10.1038/ngeo2138, 2014.

O’Connor, F. M., Johnson, C. E., Morgenstern, O., Abraham, N. L., Braesicke, P., Dalvi, M., Folberth, G. A., Sanderson, M. G., Telford, P. J., Voulgarakis, A., Young, P. J., Zeng, G., Collins, W. J. and Pyle, J. A.: Evaluation of the new UKCA climate-composition model - Part 2: The Troposphere, Geoscientific Model Development, 7(1), 41-91, doi:10.5194/gmd-741-2014, 2014.

950 Oetjen, H., Payne, V. H., Neu, J. L., Kulawik, S. S., Edwards, D. P., Eldering, A., Worden, H. M. and Worden, J. R.: A joint data record of tropospheric ozone from Aura-TES and MetOp-IASI, Atmospheric Chemistry and Physics, 16(15), 1022910239, doi:10.5194/acp-16-10229-2016, 2016.

Olsen, M. A., Manney, G. L. and Liu, J.: The ENSO and QBO Impact on Ozone Variability and Stratosphere-Troposphere Exchange Relative to the Subtropical Jets, Journal of Geophysical Research: Atmospheres, doi:10.1029/2019jd030435,

Oman, L. D., Douglass, A. R., Ziemke, J. R., Rodriguez, J. M., Waugh, D. W. and Nielsen, J. E.: The ozone response to ENSO in Aura satellite measurements and a chemistry-climate simulation, Journal of Geophysical Research: Atmospheres, 118(2), 965-976, doi:10.1029/2012jd018546, 2013.

Pacifico, F., Harrison, S. P., Jones, C. D., Arneth, A., Sitch, S., Weedon, G. P., Barkley, M. P., Palmer, P. I., Serça, D., 960 Potosnak, M., Fu, T.-M., Goldstein, A., Bai, J. and Schurgers, G.: Evaluation of a photosynthesis-based biogenic isoprene emission scheme in JULES and simulation of isoprene emissions under present-day climate conditions, Atmospheric Chemistry and Physics, 11(9), 4371-4389, doi:10.5194/acp-11-4371-2011, 2011.

Parrish, D. D., Lamarque, J.-F., Naik, V., Horowitz, L., Shindell, D. T., Staehelin, J., Derwent, R., Cooper, O. R., Tanimoto, H., Volz-Thomas, A., Gilge, S., Scheel, H.-E., Steinbacher, M. and Fröhlich, M.: Long-term changes in lower tropospheric

965 baseline ozone concentrations: Comparing chemistry-climate models and observations at northern midlatitudes, Journal of Geophysical Research: Atmospheres, 119(9), 5719-5736, doi:10.1002/2013jd021435, 2014.

Paulot, F., Henze, D. K. and Wennberg, P. O.: Impact of the isoprene photochemical cascade on tropical ozone, Atmospheric Chemistry and Physics, 12(3), 1307-1325, doi:10.5194/acp-12-1307-2012, 2012.

Pausata, F. S. R., Pozzoli, L., Vignati, E. and Dentener, F. J.: North Atlantic Oscillation and tropospheric ozone variability in

970 Europe: model analysis and measurements intercomparison, Atmospheric Chemistry and Physics, 12(14), 6357-6376, doi:10.5194/acp-12-6357-2012, 2012.

Pickering, K. E., Thompson, A. M., Dickerson, R. R., Luke, W. T., McNamara, D. P., Greenberg, J. P. and Zimmerman, P. R.: Model calculations of tropospheric ozone production potential following observed convective events, Journal of Geophysical Research, 95(D9), 14049, doi:10.1029/jd095id09p14049, 1990.

975 Pope, R. J., Chipperfield, M. P., Arnold, S. R., Glatthor, N., Feng, W., Dhomse, S. S., Kerridge, B. J., Latter, B. G. and Siddans, R.: Influence of the wintertime North Atlantic Oscillation on European tropospheric composition: an observational and modelling study, Atmospheric Chemistry and Physics, 18(11), 8389-8408, doi:10.5194/acp-18-8389-2018, 2018.

Portmann, R. W. and Solomon, S.: Indirect radiative forcing of the ozone layer during the 21 st century, Geophysical Research Letters, 34(2), doi:10.1029/2006g1028252, 2007. 
Price, C. and Rind, D.: A simple lightning parameterization for calculating global lightning distributions, Journal of Geophysical Research: Atmospheres, 97(D9), 9919-9933, doi:10.1029/92jd00719, 1992.

Reutter, P., Škerlak, B., Sprenger, M. and Wernli, H.: Stratosphere-troposphere exchange (STE) in the vicinity of North Atlantic cyclones, Atmospheric Chemistry and Physics, 15(19), 10939-10953, doi:10.5194/acp-15-10939-2015, 2015.

Reverdin, G.: North Atlantic Subpolar Gyre Surface Variability (1895-2009), Journal of Climate, 23(17), 4571-4584, doi:10.1175/2010jcli3493.1, 2010.

Roberts, G., Wooster, M. J. and Lagoudakis, E.: Annual and diurnal african biomass burning temporal dynamics, Biogeosciences, 6(5), 849-866, doi:10.5194/bg-6-849-2009, 2009.

Robson, J., Ortega, P. and Sutton, R.: A reversal of climatic trends in the North Atlantic since 2005, Nature Geoscience, 9(7), 513-517, doi:10.1038/ngeo2727, 2016.

990 Robson, J., Sutton, R. T., Archibald, A., Cooper, F., Christensen, M., Gray, L. J., Holliday, N. P., Macintosh, C., McMillan, M., Moat, B., Russo, M., Tilling, R., Carslaw, K., Desbruyères, D., Embury, O., Feltham, D. L., Grosvenor, D. P., Josey, S., King, B., Lewis, A., McCarthy, G. D., Merchant, C., New, A. L., O’Reilly, C. H., Osprey, S. M., Read, K., Scaife, A., Shepherd, A., Sinha, B., Smeed, D., Smith, D., Ridout, A., Woollings, T. and Yang, M.: Recent multivariate changes in the North Atlantic climate system, with a focus on 2005-2016, International Journal of Climatology, 38(14), 5050-5076, doi:10.1002/joc.5815, 2018.

Santer, B. D., Wigley, T. M. L., Gaffen, D. J., Bengtsson, L., Doutriaux, C., Boyle, J. S., Esch, M., Hnilo, J. J., Jones, P. D., Meehl, G. A., Roeckner, E., Taylor, K. E. and Wehner, M. F.: Interpreting Differential Temperature Trends at the Surface and in the Lower Troposphere, Science, 287(5456), 1227-1232, doi:10.1126/science.287.5456.1227, 2000.

Sátori, G., Williams, E. and Lemperger, I.: Variability of global lightning activity on the ENSO time scale, Atmospheric Research, 91(2-4), 500-507, doi:10.1016/j.atmosres.2008.06.014, 2009.

Schumann, U. and Huntrieser, H.: The global lightning-induced nitrogen oxides source, Atmospheric Chemistry and Physics, 7(14), 3823-3907, doi:10.5194/acp-7-3823-2007, 2007.

Sellar, A. A., Jones, C. G., Mulcahy, J. P., Tang, Y., Yool, A., Wiltshire, A., O'Connor, F. M., Stringer, M., Hill, R., Palmieri, J., Woodward, S., Mora, L., Kuhlbrodt, T., Rumbold, S. T., Kelley, D. I., Ellis, R., Johnson, C. E., Walton, J.,

1005 Abraham, N. L., Andrews, M. B., Andrews, T., Archibald, A. T., Berthou, S., Burke, E., Blockley, E., Carslaw, K., Dalvi, M., Edwards, J., Folberth, G. A., Gedney, N., Griffiths, P. T., Harper, A. B., Hendry, M. A., Hewitt, A. J., Johnson, B., Jones, A., Jones, C. D., Keeble, J., Liddicoat, S., Morgenstern, O., Parker, R. J., Predoi, V., Robertson, E., Siahaan, A., Smith, R. S., Swaminathan, R., Woodhouse, M. T., Zeng, G. and Zerroukat, M.: UKESM1: Description and Evaluation of the U.K. Earth System Model, Journal of Advances in Modeling Earth Systems, 11(12), 4513-4558,

1010 doi:10.1029/2019ms001739, 2019.

Škerlak, B., Sprenger, M. and Wernli, H.: A global climatology of stratosphere-troposphere exchange using the ERAInterim data set from 1979 to 2011, Atmospheric Chemistry and Physics, 14(2), 913-937, doi:10.5194/acp-14-913-2014, 2014.

Smeed, D. A., Josey, S. A., Beaulieu, C., Johns, W. E., Moat, B. I., Frajka-Williams, E., Rayner, D., Meinen, C. S., Baringer, 1015 M. O., Bryden, H. L. and McCarthy, G. D.: The North Atlantic Ocean Is in a State of Reduced Overturning, Geophysical Research Letters, 45(3), 1527-1533, doi:10.1002/2017g1076350, 2018.

Squire, O. J., Archibald, A. T., Griffiths, P. T., Jenkin, M. E., Smith, D. and Pyle, J. A.: Influence of isoprene chemical mechanism on modelled changes in tropospheric ozone due to climate and land use over the 21st century, Atmospheric Chemistry and Physics, 15(9), 5123-5143, doi:10.5194/acp-15-5123-2015, 2015.

1020 Steinbrecht, W., Hegglin, M. I., Harris, N. and Weber, M.: Is global ozone recovering?, Comptes Rendus Geoscience, 350(7), 368-375, doi:10.1016/j.crte.2018.07.012, 2018. 
Sutton, R. T., McCarthy, G. D., Robson, J., Sinha, B., Archibald, A. T. and Gray, L. J.: Atlantic Multidecadal Variability and the U.K. ACSIS Program, Bulletin of the American Meteorological Society, 99(2), 415-425, doi:10.1175/bams-d-16-0266.1, 2018.

1025 Swart, N. C., Fyfe, J. C., Hawkins, E., Kay, J. E. and Jahn, A.: Influence of internal variability on Arctic sea-ice trends, Nature Climate Change, 5(2), 86-89, doi:10.1038/nclimate2483, 2015.

Tarasick, D., Galbally, I. E., Cooper, O. R., Schultz, M. G., Ancellet, G., Leblanc, T., Wallington, T. J., Ziemke, J., Liu, X., Steinbacher, M., Staehelin, J., Vigouroux, C., Hannigan, J. W., García, O., Foret, G., Zanis, P., Weatherhead, E., Petropavlovskikh, I., Worden, H., Osman, M., Liu, J., Chang, K.-L., Gaudel, A., Lin, M., Granados-Muñoz, M., Thompson,

1030 A. M., Oltmans, S. J., Cuesta, J., Dufour, G., Thouret, V., Hassler, B., Trickl, T. and Neu, J. L.: Tropospheric Ozone Assessment Report: Tropospheric ozone from 1877 to 2016, observed levels, trends and uncertainties, edited by D. Helmig and A. Lewis, Elementa: Science of the Anthropocene, 7, doi:10.1525/elementa.376, 2019.

Telford, P. J., Braesicke, P., Morgenstern, O. and Pyle, J. A.: Technical Note: Description and assessment of a nudged version of the new dynamics Unified Model, Atmospheric Chemistry and Physics, 8(6), 1701-1712, doi:10.5194/acp-8-

1035 1701-2008, 2008.

Terao, Y., Logan, J. A., Douglass, A. R. and Stolarski, R. S.: Contribution of stratospheric ozone to the interannual variability of tropospheric ozone in the northern extratropics, Journal of Geophysical Research, 113(D18), doi:10.1029/2008jd009854, 2008.

Tweedy, O. V., Waugh, D. W., Randel, W. J., Abalos, M., Oman, L. D. and Kinnison, D. E.: The Impact of Boreal Summer

1040 ENSO Events on Tropical Lower Stratospheric Ozone, Journal of Geophysical Research: Atmospheres, 123(17), 9843-9857, doi:10.1029/2018jd029020, 2018.

Van der Werf, G. R., Randerson, J. T., Giglio, L., van Leeuwen, T. T., Chen, Y., Rogers, B. M., Mu, M., van Marle, M. J. E., Morton, D. C., Collatz, G. J., Yokelson, R. J. and Kasibhatla, P. S.: Global fire emissions estimates during 1997-2016, Earth System Science Data, 9(2), 697-720, doi:10.5194/essd-9-697-2017, 2017.

1045 Von Clarmann, T. and Glatthor, N.: The application of mean averaging kernels to mean trace gas distributions, Atmospheric Measurement Techniques, 12(9), 5155-5160, doi:10.5194/amt-12-5155-2019, 2019.

Walters, D., Baran, A. J., Boutle, I., Brooks, M., Earnshaw, P., Edwards, J., Furtado, K., Hill, P., Lock, A., Manners, J., Morcrette, C., Mulcahy, J., Sanchez, C., Smith, C., Stratton, R., Tennant, W., Tomassini, L., Van Weverberg, K., Vosper, S., Willett, M., Browse, J., Bushell, A., Carslaw, K., Dalvi, M., Essery, R., Gedney, N., Hardiman, S., Johnson, B., Johnson, C.,

1050 Jones, A., Jones, C., Mann, G., Milton, S., Rumbold, H., Sellar, A., Ujiie, M., Whitall, M., Williams, K. and Zerroukat, M.: The Met Office Unified Model Global Atmosphere 7.0/7.1 and JULES Global Land 7.0 configurations, Geoscientific Model Development, 12(5), 1909-1963, doi:10.5194/gmd-12-1909-2019, 2019.

Wang, L., Newchurch, M. J., Pour-Biazar, A., Kuang, S., Khan, M., Liu, X., Koshak, W. and Chance, K.: Estimating the influence of lightning on upper tropospheric ozone using NLDN lightning data and CMAQ model, Atmospheric

1055 Environment, 67, 219-228, doi:10.1016/j.atmosenv.2012.11.001, 2013.

Waters, J. W., Froidevaux, L., Harwood, R. S., Jarnot, R. F., Pickett, H. M., Read, W. G., Siegel, P. H., Cofield, R. E., Filipiak, M. J., Flower, D. A., Holden, J. R., Lau, G. K., Livesey, N. J., Manney, G. L., Pumphrey, H. C., Santee, M. L., Wu, D. L., Cuddy, D. T., Lay, R. R., Loo, M. S., Perun, V. S., Schwartz, M. J., Stek, P. C., Thurstans, R. P., Boyles, M. A., Chandra, K. M., Chavez, M. C., Gun-Shing Chen, Chudasama, B. V., Dodge, R., Fuller, R. A., Girard, M. A., Jiang, J. H., 1060 Yibo Jiang, Knosp, B. W., LaBelle, R. C., Lam, J. C., Lee, K. A., Miller, D., Oswald, J. E., Patel, N. C., Pukala, D. M., Quintero, O., Scaff, D. M., Van Snyder, W., Tope, M. C., Wagner, P. A. and Walch, M. J.: The Earth observing system microwave limb sounder (EOS MLS) on the aura Satellite, IEEE Transactions on Geoscience and Remote Sensing, 44(5), 1075-1092, doi:10.1109/tgrs.2006.873771, 2006.

Weber, J., Archer-Nicholls, S., Abraham, N. L., Shin, Y. M., Bannan, T. J., Percival, C. J., Bacak, A., Artaxo, P., Jenkin, M., 
https://doi.org/10.5194/acp-2022-99

Preprint. Discussion started: 2 March 2022

(c) Author(s) 2022. CC BY 4.0 License.

Atmospheric

Chemistry

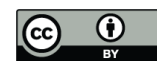

and Physics

Discussions

of BVOC chemistry-climate interactions in UKCA (v11.5) with the CRI-Strat 2 mechanism: incorporation and evaluation, Geoscientific Model Development, 14(8), 5239-5268, doi:10.5194/gmd-14-5239-2021, 2021.

Weber, M., Coldewey-Egbers, M., Fioletov, V. E., Frith, S. M., Wild, J. D., Burrows, J. P., Long, C. S. and Loyola, D.: Total ozone trends from 1979 to 2016 derived from five merged observational datasets - the emergence into ozone recovery, Atmospheric Chemistry and Physics, 18(3), 2097-2117, doi:10.5194/acp-18-2097-2018, 2018.

Wigley, T. M. L., Santer, B. D., Lanzante, J. R.: Appendix A: Statistical issues regarding trends. In: Karl, T. R., Hassol, S. J., Miller, C. D. and Murray, W. L.: Temperature Trends in the Lower Atmosphere: Steps for Understanding and Reconciling Differences. A Report by the U.S. Climate Change Science Program and the Subcommittee on Global Change Research., 129-139, https://library.wmo.int/doc_num.php?explnum_id=6347, 2006.

1075 Williams, R. S., Hegglin, M. I., Kerridge, B. J., Jöckel, P., Latter, B. G. and Plummer, D. A.: Characterising the seasonal and geographical variability in tropospheric ozone, stratospheric influence and recent changes, Atmospheric Chemistry and Physics, 19(6), 3589-3620, doi:10.5194/acp-19-3589-2019, 2019.

WMO (World Meteorological Organization), Scientific Assessment of Ozone Depletion: 2018, Global Ozone Research and Monitoring Project - Report No. 58, 588 pp., Geneva, Switzerland, 2018.

1080 Woollings, T., Franzke, C., Hodson, D. L. R., Dong, B., Barnes, E. A., Raible, C. C. and Pinto, J. G.: Contrasting interannual and multidecadal NAO variability, Climate Dynamics, 45(1-2), 539-556, doi:10.1007/s00382-014-2237-y, 2014.

Yang, H., Chen, G., Tang, Q. and Hess, P.: Quantifying isentropic stratosphere-troposphere exchange of ozone, Journal of Geophysical Research: Atmospheres, 121(7), 3372-3387, doi:10.1002/2015jd024180, 2016.

Yeung, L. Y., Murray, L. T., Martinerie, P., Witrant, E., Hu, H., Banerjee, A., Orsi, A. and Chappellaz, J.: Isotopic constraint on the twentieth-century increase in tropospheric ozone, Nature, 570(7760), 224-227, doi:10.1038/s41586-019-1277-1, 2019.

Young, P. J., Archibald, A. T., Bowman, K. W., Lamarque, J.-F., Naik, V., Stevenson, D. S., Tilmes, S., Voulgarakis, A., Wild, O., Bergmann, D., Cameron-Smith, P., Cionni, I., Collins, W. J., Dalsøren, S. B., Doherty, R. M., Eyring, V., Faluvegi, G., Horowitz, L. W., Josse, B., Lee, Y. H., MacKenzie, I. A., Nagashima, T., Plummer, D. A., Righi, M.,

1090 Rumbold, S. T., Skeie, R. B., Shindell, D. T., Strode, S. A., Sudo, K., Szopa, S. and Zeng, G.: Pre-industrial to end 21st century projections of tropospheric ozone from the Atmospheric Chemistry and Climate Model Intercomparison Project (ACCMIP), Atmospheric Chemistry and Physics, 13(4), 2063-2090, doi:10.5194/acp-13-2063-2013, 2013.

Young, P. J., Naik, V., Fiore, A. M., Gaudel, A., Guo, J., Lin, M. Y., Neu, J. L., Parrish, D. D., Rieder, H. E., Schnell, J. L., Tilmes, S., Wild, O., Zhang, L., Ziemke, J., Brandt, J., Delcloo, A., Doherty, R. M., Geels, C., Hegglin, M. I., Hu, L., Im, U.,

1095 Kumar, R., Luhar, A., Murray, L., Plummer, D., Rodriguez, J., Saiz-Lopez, A., Schultz, M. G., Woodhouse, M. T. and Zeng, G.: Tropospheric Ozone Assessment Report: Assessment of global-scale model performance for global and regional ozone distributions, variability, and trends, edited by D. Helmig and A. Lewis, Elementa: Science of the Anthropocene, 6 , doi:10.1525/elementa.265, 2018.

Ziemke, J. R., Chandra, S., Oman, L. D. and Bhartia, P. K.: A new ENSO index derived from satellite measurements of $\lfloor 100$ column ozone, Atmospheric Chemistry and Physics, 10(8), 3711-3721, doi:10.5194/acp-10-3711-2010, 2010.

Ziemke, J. R., Chandra, S., Duncan, B. N., Froidevaux, L., Bhartia, P. K., Levelt, P. F. and Waters, J. W.: Tropospheric ozone determined from Aura OMI and MLS: Evaluation of measurements and comparison with the Global Modeling Initiative's Chemical Transport Model, Journal of Geophysical Research, 111(D19), doi:10.1029/2006jd007089, 2006.

Ziemke, J. R., Chandra, S., McPeters, R. D. and Newman, P. A.: Dynamical proxies of column ozone with applications to global trend models, Journal of Geophysical Research: Atmospheres, 102(D5), 6117-6129, doi:10.1029/96jd03783, 1997.

Ziemke, J. R., Oman, L. D., Strode, S. A., Douglass, A. R., Olsen, M. A., McPeters, R. D., Bhartia, P. K., Froidevaux, L., Labow, G. J., Witte, J. C., Thompson, A. M., Haffner, D. P., Kramarova, N. A., Frith, S. M., Huang, L.-K., Jaross, G. R., Seftor, C. J., Deland, M. T. and Taylor, S. L.: Trends in global tropospheric ozone inferred from a composite record of 
https://doi.org/10.5194/acp-2022-99

Preprint. Discussion started: 2 March 2022

(C) Author(s) 2022. CC BY 4.0 License.

(c) (1)

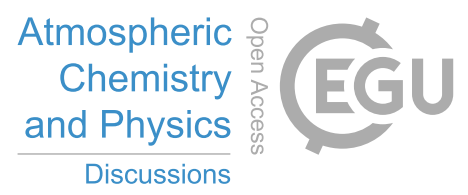

TOMS/OMI/MLS/OMPS satellite measurements and the MERRA-2 GMI simulation, Atmospheric Chemistry and Physics, 1110 19(5), 3257-3269, doi:10.5194/acp-19-3257-2019, 2019. 